\title{
Excitatory Actions of Norepinephrine on Multiple Classes of Hippocampal CA1 Interneurons
}

\author{
Dwight E. Bergles, Van A. Doze, Daniel V. Madison, and Stephen J. Smith \\ Department of Molecular and Cellular Physiology, Beckman Center for Molecular and Genetic Medicine, Stanford \\ University School of Medicine, Stanford, California 94305-5426
}

\begin{abstract}
Norepinephrine (NE) causes an increase in the frequency of inhibitory postsynaptic potentials in CA1 pyramidal neurons in vitro. The possibility that this increase in tonic inhibition is caused by an excitatory effect on inhibitory interneurons was investigated through whole-cell recordings from pyramidal cells and both whole-cell and cell-attached patch recordings from visualized interneurons in acute slices of rat hippocampus. Adrenergic agonists caused a large increase in the frequency and amplitude of spontaneous IPSCs recorded from pyramidal cells in the presence of ionotropic glutamate receptor blockers, but they had no effect on either the frequency or the amplitude of action potential-independent miniature IPSCs recorded in tetrodotoxin. This effect was mediated primarily by an $\alpha$ adrenoceptor, although a slight $\beta$ adrenoceptor-dependent increase in IPSCs was also observed.

NE caused interneurons located in all strata to depolarize and begin firing action potentials. Many of these cells had axons that ramified throughout the stratum pyramidale, suggesting that they are responsible for the IPSCs observed in pyramidal neurons. This depolarization was also mediated by an $\alpha$ adrenoceptor and was blocked by a selective $\alpha_{1}$ - but not a selective $\alpha_{2}$-adrenoceptor antagonist. However, a slight $\beta$ adrenoceptor-
\end{abstract}

dependent depolarization was detected in those interneurons that displayed time-dependent inward rectification. In the presence of a $\beta$ antagonist, NE induced an inward current that reversed near the predicted $\mathrm{K}^{+}$equilibrium potential and was not affected by changes in intracellular $\mathrm{Cl}^{-}$concentration. In the presence of an $\alpha_{1}$ antagonist, NE induced an inwardly rectifying current at potentials negative to approximately -70 $\mathrm{mV}$ that did not reverse (between -130 and $-60 \mathrm{mV}$ ), characteristics similar to the hyperpolarization-activated current $\left(I_{\mathrm{n}}\right)$. However, the depolarizing action of NE is attributable primarily to the $\alpha_{1}$ adrenoceptor-mediated decrease in $\mathrm{K}^{+}$conductance and not the $\beta$ adrenoceptor-dependent increase in $I_{\mathrm{h}}$.

These results provide evidence that NE increases action potential-dependent IPSCs in pyramidal neurons by depolarizing surrounding inhibitory interneurons. This potent excitatory action of NE on multiple classes of hippocampal interneurons may contribute to the NE-induced decrease in the spontaneous activity of pyramidal neurons and the antiepileptic effects of NE observed in vivo.

Key words: norepinephrine; interneuron; $\alpha$ adrenoceptor; hippocampus; GABA; IPSC; epilepsy; CA1
Norepinephrine (NE) has prominent inhibitory effects in the in vivo hippocampus. Stimulation of the locus ceruleus, the origin of the noradrenergic projection to the hippocampus (Loy et al., 1980 ), rcduces the spontancous activity of pyramidal neurons (Segal and Bloom, 1974b; Curet and de Montigny, 1988b). The mechanisms responsible for this inhibition appear to reside in the hippocampus because direct application of NE, via either iontophoresis or pressure injection, also decreases the firing rate of pyramidal cells (Segal and Bloom, 1974a; Mueller et al., 1982; Pang and Rose, 1987; Curet and de Montigny, 1988a). The hip-

Received July 3, 1995; revised Oct. 3, 1995; accepted Oct. 4, 1995.

This work was supported by an NSF predoctoral fellowship to D.E.B. and an NIMH predoctoral fellowship to V.A.D. Additional support was provided by grants from the National Institute of Mental Health Silvio Conte Center for Neuroscience Research to D.V.M. and S.JS. (MH48108), the National Institute of Mental Health to D.V.M. (NS12151), and the Lucille P. Markey Charitable Trust. D.V.M. is a Lucille P. Markey Scholar in Biomedical Sciences. We are especially grateful to Dr. Kenneth L. Kirk of the NIDDK (Bethesda, MD) for providing the fluorinated catecholamine 6-fluoroepincphrine, and to Drs. Bertil Takman and James Hedge of Astra Pharmaceuticals (Westborough, MA) for the gift of QX-314. We also thank Dr. Gal Cohcn and Eric Schiable for writing data acquisition and analysis software, and Isabel Parada for assistance with the slice histology.

Correspondence should be addressed to Daniel V. Madison, Department of Molecular and Cellular Physiology, Beckman Center, Room B-111B, Stanford University School of Medicine, Stanford, CA 94305-5426.

Dr. Bergles' present address: Vollum Institute, Oregon Health Sciences University, Portland, OR 97201-3098.

Copyright $\odot 1996$ Society for Neuroscience $0270-6474 / 96 / 160572-14 \$ 05.00 / 0$ pocampal noradrenergic system is also potently antiepileptic in vivo. Stimulation of the locus ceruleus decreases the susceptibility to both kindling-induced and pharmacologically induced seizures (for review, see Chauvel and Trottier, 1986). However, little is known about the sites of action and cellular mechanisms responsible for these inhibitory and antiepileptic effects.

Synaptic inhibition in the hippocampus is generated by a diverse group of local circuit interneurons that receive excitatory input from feedforward and feedback pathways and release GABA onto principal cells (Andersen et al., 1964; Knowles and Schwartzkroin, 1981; Miles and Wong, 1984; Lacaille et al., 1987; Lacaille and Schwartzkroin, 1988b; Buhl et al., 1994a). Numerous light- and electron microscopic studies have demonstrated an overlapping distribution of catecholaminergic and GABAergic processes (Babb et al., 1988; Milner and Bacon, 1989a) and direct synaptic relationships between catecholamine-containing nerve terminals and GABA-containing neurons (Frotscher and Leranth, 1988; Milner and Bacon, 1989b). These studies suggest that GABAergic cells are an important target of the catecholaminergic projections to the hippocampus.

$\mathrm{NE}$ can increase the level of tonic inhibition potently in area CA1 of the hippocampus, as measured by an increase in spontaneously occurring IPSPs in pyramidal cells (Madison and Nicoll, 1988a). This effect on IPSP frequency persists in the presence of 
glutamate receptor antagonists, suggesting that NE has a direct excitatory action on hippocampal interneurons (Doze et al., 1991). Pang and Rose (1987) demonstrated that the firing rate of $\theta$ cells (presumed to be interneurons) was increased by $\mathrm{NE}$ in single-unit recordings from the in vivo hippocampus, providing further evidence that NE can excite local inhibitory interneurons. However, in contrast to the well defined excitatory actions of NE on pyramidal cells (for review, see Nicoll et al., 1990), little is known about the direct effects of NE on interneurons. The low density and wide distribution of these local circuit inhibitory neurons have made them largely inaccessible to conventional "blind" recording techniques. In this study, we used whole-cell recording methods (Edwards et al., 1989) coupled with infrared/ Nomarski imaging (Dodt and Zieglgansberger, 1990) in acute slices of rat hippocampus to examine the direct actions of adrenergic agonists on this morphologically diverse group of cells. We present evidence that NE potently depolarizes and increases the firing rate of interneurons found in all strata of area CA1, a result of an $\alpha_{1}$ adrenoceptor-dependent reduction in resting $\mathrm{K}^{+}$conductance that may contribute to the global inhibitory effects of $\mathrm{NE}$ described in vivo.

Some of these results have been published previously in abstract form (Doze et al., 1993).

\section{MATERIALS AND METHODS}

Slice preparation. Hippocampal slices were prepared from male SpragueDawley rats (150-250 gm) using standard methods (Madison and Nicoll, 1986) and in strict accordance with a protocol set by the Stanford University Animal Use and Care Committee. Hippocampi were dissected from the brain, placed in ice-cold artificial CSF (ACSF), and cut transversely into $400-500 \mu \mathrm{m}$ slices using a conventional tissue-sectioning apparatus (Stoelting, Hamburg, Germany). Slices were then allowed to recover $(>1 \mathrm{hr})$ in a humidified chamber while resting on filter paper moistened with ACSF. During experimentation, slices were superfused continuously at a rate of $2-4 \mathrm{cc} / \mathrm{min}$ with oxygenated $\left(95 \% \mathrm{O}_{2} / 5 \% \mathrm{CO}_{2}\right)$ ACSF containing (in mM): $\mathrm{NaCl} 119 ; \mathrm{KCl} 2.5,3.5$, or 5 as noted; $\mathrm{MgSO}_{4}$ 1.3; $\mathrm{CaCl}_{2} 2.5 ; \mathrm{NaH}_{2} \mathrm{PO}_{4} 1 ; \mathrm{NaCO}_{3} 26.2 ;$ glucose 11 . All experiments were performed at room temperature $\left(22-24^{\circ} \mathrm{C}\right)$.

Pyramidal cell recordings. Spontaneous inhibitory postsynaptic currents (IPSCs) were recorded from CA1 pyramidal neurons that were obtained using previously described "blind" whole-cell recording techniques (Blanton et al., 1989). Cells were voltage-clamped at their resting potential $(-50$ to $-67 \mathrm{mV}$ ) using an Axoclamp $2 \mathrm{~A}$ (Axon Instruments, Foster City, $\mathrm{CA}$ ), and currents were amplified $10 \times$, filtered at $1 \mathrm{kHz}$ (Brownlee Precision 210A, Santa Clara, CA), and digitized using programs written in Axobasic (Axon Instruments). Series resistance effects were partially compensated using the Axoclamp circuitry, and access resistance (20-40 $\mathrm{M} \Omega$ ) was monitored continuously (every $30 \mathrm{sec}$ ) during each expcriment. Experiments were discarded if the access resistance changed by greater than $\sim 15 \%$ as judged by eye. The whole-cell electrode solution contained (in mM): $\mathrm{KCl} 100$, EGTA 10, HEPES 40, $\mathrm{MgCl}_{2}$ 5, ATP-Na salt 2, GTP-Na salt 0.3, QX-314 1, pH 7.2. Chloride was used as a permeant anion in the internal solution to reverse the polarity and increase the amplitude of $\mathrm{GABA}_{\mathrm{A}}$ receptor-mediated IPSCs, and the quaternary lidocaine derivative QX-314 (1 mM) (Astra, Westborough, MA) was also included in the internal solution to prevent depolarizing IPSCs from triggering action potentials. The extracellular potassium concentration $\left(\left[\mathrm{K}^{+}\right]_{\mathrm{o}}\right)$ was raised to $5 \mathrm{mM}$ in these experiments to ensure an appropriate level of basal activity. Some experiments were done in the presence of 10 $\mu \mathrm{M}$ 6-cyano-7-nitroquinoxaline-2,3-dione (CNQX) and $50 \mu \mathrm{M} 2$-amino5-phosphonovalerate (APV) to block glutaminergic transmission and, in some instances, $1 \mu \mathrm{M}$ tetrodotoxin (TTX) was uscd to block all action potential-mediated neurotransmitter release.

Interneuron recordings. Slices were transferred to a Lucite chamber with a removable coverslip bottom and held in place with acetate pins. The chamber was attached to a custom stage built from Newport parts (Newport, CA) with two motorized three-axis manipulators (Zeiss, Rockford, IL) attached. Interneurons were visualized on an upright microscope (Zeiss) with infrared (IR) light (Melles Groit RG850 filter, Irvine, $\mathrm{CA}$ ) and Nomarski optics using a $40 \times$ water-immersion objective (Zeiss;
NA 0.75) and a charge-coupled device camera (Sony XC-77) with the standard IR-blocking filter removed. Using these optics, interneurons were clearly visible at tissue depths of up to $\sim 250 \mu \mathrm{m}$ in $400-500 \mu \mathrm{m}$ slices and could be patched reliably at depths of $>150 \mu \mathrm{m}$. Patch electrodes were pulled from VWR $100 \mu$ l micropipette glass using a three-stage pull (Sutter Instrument P-87, Novato, CA) to a tip diamctcr of $\sim 2 \mu \mathrm{m}$ and had a resistance of 4-7 $\mathrm{M} \Omega$ (potassium gluconate). Interneurons were identified initially by their location in strata other than stratum (s.) pyramidale and were approached with positive pressure. After contact, slight negative pressure was applied and seals (2-10 G $\Omega$ ) formed slowly with negative holding current. After seal formation, the membrane under the pipette was ruptured with additional negative pressure or brief hyperpolarizing current or, alternatively, the seal was left infact and extracellular action potentials were recorded in voltage clamp. For cell-attached patch recordings, the patch was held at $\sim 0 \mathrm{mV}$ (pipette potential $\simeq-60 \mathrm{mV}$ ) and, at the conclusion of the experiment, the integrity of the patch was tested by performing a ramp depolarization. If any change in action potential frequency was detected, the experiment was discarded. Whole-cell and patch currents or membrane potentials were recorded with either an Axoclamp 2A or an Axopalch 2C (Axon Instruments), amplified 10-100× (Brownlee 210A), and filtered at the Nyquist frequency using an 8-pole Bessel filter (Frequency Devices, Menlo Park, CA). Series resistance effects were partially compensated using the Axoclamp circuitry, and adjustments to the recorded membrane potential were made by measuring any offset at the end of the recording after destroying the seal. The standard internal solution used for these recordings contained (in mM): K-gluconate 100, EGTA 10, HEPES 40, $\mathrm{MgCl}_{2}$ 5, ATP-Na salt 2, GTP-Na salt 1.5, $\mathrm{pH} 7.2$.

Data analysis. Data were digitized at $1-30 \mathrm{kHz}$ with a Scientific Solutions $125 \mathrm{kHz}$ Labmaster analog-to-digital converter (TL-125, Axon Instruments) and analyzed using either pClamp software or programs written in Axobasic or Labview (National Instruments, Meriden, CT) The frequency and amplitude of spontaneous IPSCs were determined off-line using software that differentiated each sweep and used a combination of criteria, including values for the $d_{i} / d_{t}$, the first derivative of current $(i) /$ time $(t)$, of both the rising and falling phases of putative events as well as maximum amplitude to detect IPSCs accurately (Cohen et al., 1992). These criteria allowed the reliable detection of events as judged by eye, including events that were present on the falling phase of previous events. The amplitudes of these IPSCs were not corrected for the falling baseline; however, this resulted in only a small underestimation of their true amplitude, because the tau of decay for IPSCs is significantly slower when compared with their rise time (Otis and Mody, 1992). Amplitude histograms were constructed by averaging the number of events in $60 \mathrm{sec}$ of data unless noted otherwise.

Kolmogorov-Smirnov (K-S) statistics were used to determine whether there were statistically significant changes in the amplitude of IPSCs (Press et al., 1986; Otis et al., 1991), and the paired Student's $t$ test was used to determine whether there were statistically significant changes in the frequency of IPSCs, where appropriate. Values of $p<0.05$ and $Q_{\mathrm{KS}}(\lambda)<0.01$ were considered significant (NS $=$ not significant). Results are expressed as mean $\pm \mathrm{SD}$, and for K-S tests $n$ represents the number of experiments that was significant over the total number of experiments.

Histology. Neurobiotin (Vector, Burlingame, CA) or biocytin (Molecular Probes, Eugene, OR) (0.1-0.2\%) was included in the intracellular solution to allow subsequent visualization of ccll processes. At the cnd of the experiment, the seal was destroyed with a large hyperpolarizing current, the electrode was removed rapidly, and the slice was fixed overnight at $4^{\circ} \mathrm{C}$ in $4 \% \mathrm{p}$-formaldehyde in PBS. Slices were transferred to PBS the next day, cryoprotected in glycerol, and frozen. They were then resectioned on a vibratome (100 $\mu \mathrm{m}$ sections) and processed with avidinhorseradish peroxidase (Vector) and 3,3'-diaminobenzidine (Sigma, St Louis, MO) using standard techniques (Horikawa and Armstrong, 1988). A camera lucida (Leitz) then was used to trace those processes that traversed multiple sections.

Reagents. The pharmacological agents used in this study were dissolved in distilled water and diluted at 1:1000 in the superfusing ACSF. To minimize oxidation of the catecholamines, stock solutions were made fresh and added to oxygenated saline just before their application and high flow rates $(2-4 \mathrm{cc} / \mathrm{min})$ were mainlained. However, because of the lag time in our perfusion system $(\sim 30-90 \mathrm{sec})$, coupled with the fact that catecholamines oxidize rapidly in oxygenated saline (Hughes and Smith, 1978 ) and must compete with reuptake by functioning transporters white diffusing through the slice (Williams et al., 1985), the actual concentration to which cells were exposed is likely to be somewhat less than the 
A

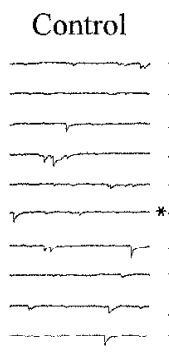

(1)

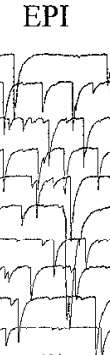

(2)

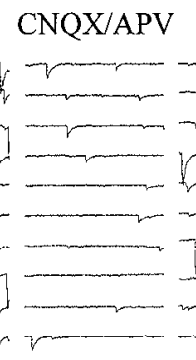

(3)
EPI

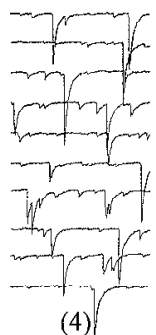

TTX

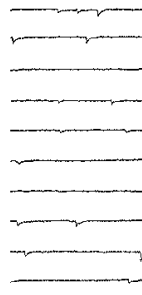

(5)

EPI

B

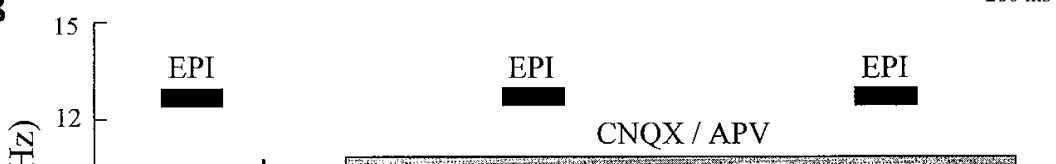

Figure 1: Effects of EPI on spontaneous IPSCs. $A$, Consecutive current traces recorded from a single CA1 pyramidal cell in whole-cell voltage clamp illustrating spontaneous IPSCs recorded during the pharmacological manipulations shown in $B$. Application of EPI $(10 \mu \mathrm{M})$ caused a large increase in IPSCs over that recorded in control (polysynaptic) conditions (EPI, Control). Compound IPSCs $\left(^{*}\right)$ sometimes were recorded in polysynaptic conditions, presumably triggered by the synchronous firing of CA3 pyramidal neurons. The glutamate receptor blockers CNQX $(10 \mu \mathrm{M})$ and $\mathrm{APV}(50 \mu \mathrm{M})$ were added to the $\mathrm{ACSF}$ to isolate interneurons from excitatory synaptic input and to block spontaneous EPSCs $(C N Q X / A P V)$. Under these monosynaptic conditions, EPI also increased the frequency of spontaneous IPSCs. Miniature IPSCs then were recorded by adding TTX $(1 \mu \mathrm{M})$ to the ACSF (TTX). EPI caused no change in the frequency of these miniature IPSCs. $B$, Frequency versus time plot for the entire experiment, with each bin representing the average IPSC frequency (in $\mathrm{Hz}$ ) for 10 consecutive sweeps. EPI caused a $>100 \%$ increase in the frequency of both polysynaptic and monosynaptic IPSCs but had no effect on the frequency of miniature IPSCs. $H_{\mathrm{p}}=-52 \mathrm{mV}$. C, Cumulative probability plots of IPSC amplitudes. EPI caused a large shift in the amplitude distribution of IPSCs recorded under both polysynaptic ( $l$ ) and monosynaptic conditions (2), reflecting an increase in the mean size of these events. In contrast, EPI did not cause any significant change in the amplitude distribution of miniature (TTX-insensitive) IPSCs (3). Similar results were obtained with NE (data not shown). $\left[\mathrm{K}^{+}\right]_{\mathrm{o}}=5 \mathrm{~mm}$.

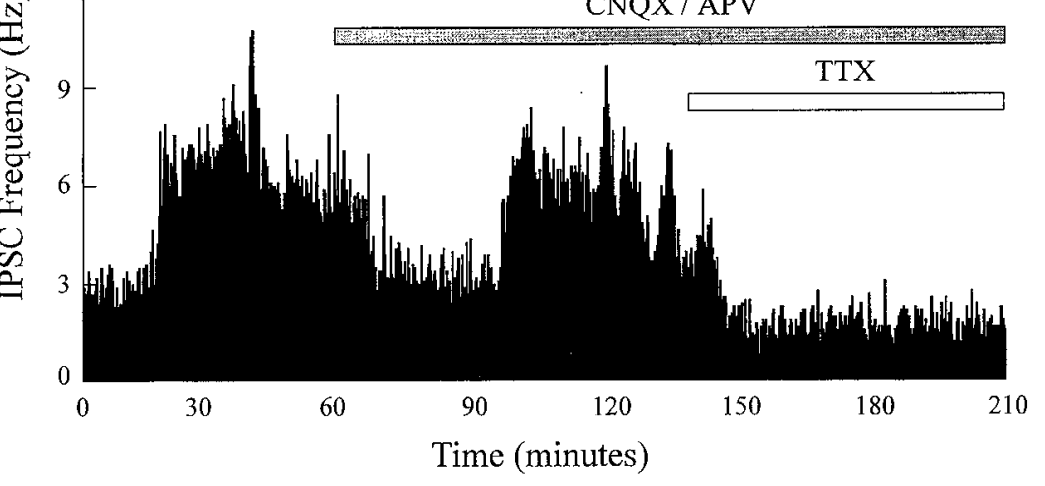

C

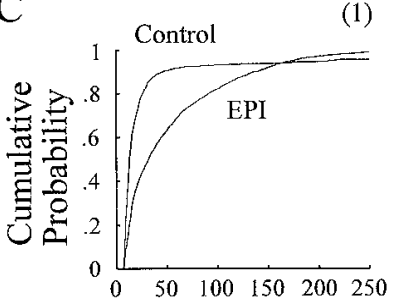

(2)
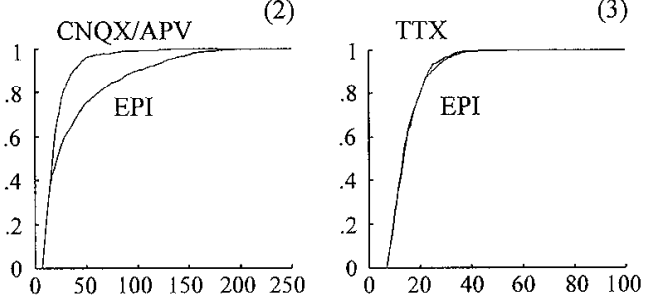

Spontaneous IPSC, Amplitude (nA) reservoir concentration. The drugs and toxins used in this study and their sources were as follows: (-)-epinephrine (EPI) bitartrate, (-)isoproterenol (ISO) bitartrate, [D-Ala ${ }^{2}$-methionine-enkephalinamide (DALA), (-)-propranolol $\mathrm{HCl}$, and picrotoxin $\mathrm{HCl}$ were from Sigma; (-)-NE bitartrate, phentolamine mesylate, 6-fluoronorepinephrine (6FNE) $\mathrm{HCl}, \mathrm{CNQX}$, and APV were from Research Biochemicals (Natick, MA); TTX was from Calbiochem (La Jolla, CA).

\section{RESULTS}

\section{Adrenergic increase in tonic inhibition}

Spontaneous IPSCs were recorded in CA1 pyramidal neurons using whole-cell electrophysiological techniques. Application of adrenergic agonists such as EPI at $10 \mu \mathrm{M}$ caused a large (>100\%) increase in the frequency of these spontaneous IPSCs under polysynaptic conditions $(3.1 \pm 2.8 \mathrm{~Hz}$, control; $7.6 \pm 1.4 \mathrm{~Hz}$, EPI; $n=5, p<0.01$; Fig. $1 A 1, A 2, B)$. This frequency increase was associated with a significant increase in the average IPSC amplitude (34 $\pm 11 \mathrm{pA}$, control; $41 \pm 11 \mathrm{pA}$, EPI; $n=5 / 5, Q_{\mathrm{KS}}(\lambda)<$ 0.01 , which resulted in a rightward shift in the cumulative amplitude distribution (Fig. 1C1). To reduce the possibility that this effect resulted from changes in the excitatory input to interneurons, spontaneous IPSCs were recorded in the presence of the ionotropic glutamate receptor blockers CNQX $(10 \mu \mathrm{M})$ and APV $(50 \mu \mathrm{M})$. The basal rate of these monosynaptic IPSCs in $5 \mathrm{~mm}$

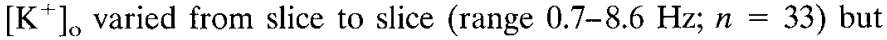
occurred at a mean rate of $\sim 4 \mathrm{~Hz}$ averaged over all experiments. Bath application of NE or EPI $(10 \mu \mathrm{M})$ caused a similar increase in the frequency of IPSCs under these conditions $(4.0 \pm 2.4 \mathrm{~Hz}$, control; $10.3 \pm 4.8 \mathrm{~Hz}$, NE or EPI; $n=19, p<0.01$; Fig. $1 A 3, A 4, B)$. Cumulative amplitude distributions of these monosynaptic IPSCs (Fig. 1C2) demonstrate that this frequency increase was also accompanied by a significant increase in the avcrage IPSC amplitude ( $24 \pm 9 \mathrm{pA}$, control; $35 \pm 17 \mathrm{pA}$, NE or EPI; $\left.n=16 / 19, Q_{\mathrm{KS}}(\lambda)<0.01\right)$.

It has been demonstrated previously that FPI does not effect the frequency of action potential-independent, or miniature, IPSPs recorded in the presence of TTX (Doze et al., 1991), suggesting that adrenergic agonists do not change the postsynaptic sensitivity to GABA. However, these experiments were not conclusive, because changes in the amplitude of these events could not be detected reliably because of the low signal-to-noise ratio inherent in microelectrode recordings. The low access resistance afforded by tight-seal, whole-cell recording allows the amplitude of these events to be measured with greater fidelity. The basal frequency of miniature IPSCs recorded from CA1 pyramidal cells in the presence of TTX $(1 \mu \mathrm{M})$ using whole-cell techniques sim- 
A

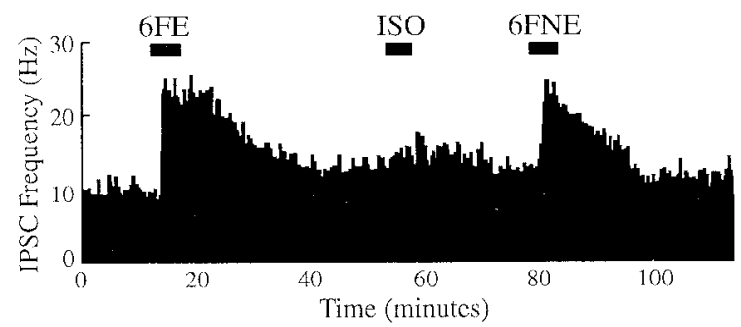

B

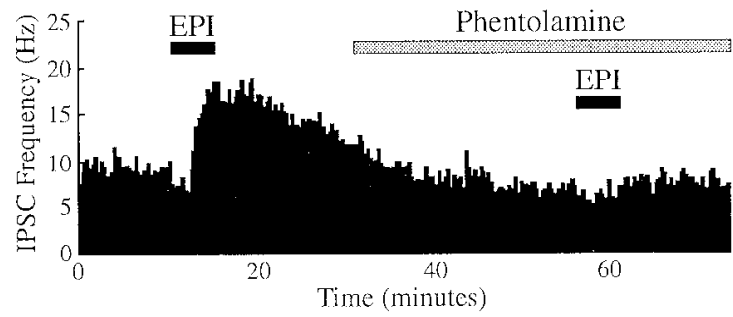

Figure 2. Pharmacology of the adrenergic agonist-induced increase in spontaneous IPSCs. A. Frequency versus time plot of IPSCs recorded from a CA1 pyramidal neuron in whole-cell voltage clamp, demonstrating that the selective $\alpha$-adrenoceptor agonists $6 \mathrm{FE}$ and $6 \mathrm{FNE}$ at $10 \mu \mathrm{v}$ caused a $>100 \%$ increase in the frequency of spontancous monosynaptic IPSCs $(6 F E, 6 F N E)$. In contrast, application of the selective $\beta$ adrenoceptor agonist ISO $(10 \mu \mathrm{M})$ resulted in only a small increase in the frequency of spontancous IPSCs $(I S O) . H_{\mathrm{p}}=-50 \mathrm{mV}$. B. Frequency versus time plots illustrating that the selective $\alpha$-adrenoceptor antagonist phentolamine (30) $\mu \mathrm{M})$ blocked the increasc in IPSC frequency produced by EPI $(10 \mu \mathrm{M})$ $(E P I) . H_{1}=-58 \mathrm{mV}$. In both experiments, the ACSF contained CNQX $(10 \mu \mathrm{M})$ and APV $(50 \mu \mathrm{M})$. $\left[\mathrm{K}^{+}\right]_{0}=5 \mathrm{mv}$.

ilarly varied widely between cells (range $0.5-2.4 \mathrm{~Hz} ; n=7$ ) with a mean rate of $\sim 1 \mathrm{~Hz}$. Under these conditions, neither the frequency $(1.2 \pm 0.7 \mathrm{~Hz}$, control; $1.2 \pm 0.8 \mathrm{~Hz}$, NE or EPI; $n=7$; NS; Fig. $1 A 5, A 6, B)$ nor the amplitude distribution of miniature IPSCs (18 $\pm 2 \mathrm{pA}$, control; $17 \pm 2 \mathrm{pA}, \mathrm{NE}$ or EPI; $n=1 / 4, Q_{\mathrm{Ks}}(\lambda)<$ 0.01 ; Fig. 1C3) was affected by EPI $(10 \mu \mathrm{M})$, suggesting that neither changes in the spontaneous release of GABA from interncuron terminals nor changes in the responsiveness to relcased GABA account for the observed increase in IPSC frequency.

The consensus of data collected in vivo suggests that an $\alpha$ adrenoceptor is primarily responsible for the inhibitory influence of NE in the hippocampus (Mueller and Dunwiddie, 1983; Pang and Rose, 1987). Stimulation of $\alpha$ adrenoceptors with the selective agonists 6-fluorocpinephrine $(6 \mathrm{FE} ; 10 \mu \mathrm{M}$ ) (Adejare et al., 1988) or 6FNE (10 $\mu \mathrm{M})$ (Cantacuzene et al., 1979) caused a significant $(>100 \%)$ increase in the frequency of spontaneous monosynaptic IPSCs $(3.8 \pm 4.3 \mathrm{~Hz}$, control; $8.1 \pm 8.6 \mathrm{~Hz}, 6 \mathrm{FE}$ or $6 \mathrm{FNE} ; n=9, p<0.01)$, whereas ISO $(10 \mu \mathrm{M})$, a selcctive $\beta$-adrenoceptor agonist, had only modest effects $(<20 \%)$ on the IPSC frequency $(4.3 \pm 5.0 \mathrm{~Hz}$, control; $5.1 \pm 6.0 \mathrm{~Hz}, \mathrm{ISO} ; n=5$; NS; Fig. 2A). In addition, the effects of EPI could be blocked by previous application of the $\alpha$-adrenoceptor antagonist phentolamine $(10-30 \mu \mathrm{m} ; n=3$; Fig. $2 B)$. Together, these data suggest that NE increases the level of tonic inhibition in hippocampal slices by stimulating $\alpha$ adrenoceptors on surrounding inhibitory interncurons.

\section{Identification and characterization of interneurons}

Location

Interneurons were identified visually by their location outside the distinct pyramidal cell layer of area CAl and by their heteroge- neous morphology. Unlike the tight stratification of pyramidal cell bodies, interneuron somata were scattered throughout all strata at a low density, consistent with the distribution of GABAimmunoreactive cells in the hippocampal formation reported previously (Woodson et al., 1989). Basket cells wore not included in this study because they were difficult to distinguish from pyramidal cells using IR/Nomarski imaging. However, several interneurons that were located just outside s. pyramidale, possibly ectopic basket cells, were recorded from and responded similarly to adrenergic agonists (see below)

\section{Electrophysiological properties}

Interneurons were readily distinguishable from pyramidal cells and glia by their membrane electrical properties and firing behavior. Interneurons had input resistances (565 $\pm 189 \mathrm{M} \Omega$, range 382-1130 $\mathrm{M} \Omega ; n=39$ ) that were 2- to 10-fold higher than those of pyramidal cells $(50-200 \mathrm{M} \Omega$ ) determined using similar wholecell techniques (Spruston and Johnston, 1992). The action potentials of interneurons ( $1.05 \pm 0.15 \mathrm{msec}$, range $0.83-1.45 \mathrm{msec} ; n=$ 39) had a shorter duration than those of pyramidal cells (1.54 \pm 0.16 msec, range $1.33-1.76 \mathrm{msec} ; n=10$ ) medsured at halfmaximal amplitude. In addition, interneuron action potentials had a smaller amplitude ( $72.8 \pm 8.4 \mathrm{mV}$, range $61.2-88.1 \mathrm{mV} ; n=39$ ) than those recorded from pyramidal cells $(84.3 \pm 8.9 \mathrm{mV}$, range $78.1-102.4 \mathrm{mV} ; n=10)$, and single spikes were followed by a rapid afterhyperpolarization (Fig. $3 A 1, B 1$, arrows). Interneurons in all strata also displayed little adaptation of action potential discharge in response to tonic depolarizing current injection (Fig. $3 A 2, B 2)$. These electrophysiological properties are similar to those described previously for inhibitory interneurons in the hippocampus (Schwartzkroin and Mathers, 1978; Lacaille and Schwartzkroin, 1988a; Kawaguchi and Hama, 1988; Lacaille and Williams, 1990; Buhl et al., 1994b).

Some electrophysiological differences were observed between interneurons located in different strata. In particular, cells located in $s$. oriens had action potentials of a larger amplitude $(79.0 \pm 8.7$ $m \mathrm{~V}$, range $67.0-88.1 \mathrm{mV} ; n-13)$ than those located in other strata $(70.8 \pm 5.0 \mathrm{mV}$, range $61.2-79.5 \mathrm{mV} ; n=26)$, and some spike frequency adaptation typically was observed in interneurons located in s. radiatum and s. lacunosum-molcculare (Fig. 3B2). Interneurons also displayed variable amounts of time-dependent inward rectification in response to a constant-current hyperpolarizing step, visible as a relaxation of the membrane potential toward the resting level (Fig. 3C1, arrow). However, some cells appeared to lack this anomalous rectification entirely $(n=8 / 39$; Fig. $3 C 2$ ). The presence of time-dependent rectification was correlated with cell size but not location, with appreciable rectification typically found only in cclls with visibly larger somata and larger whole-cell capacitances. All interncurons comprising the above data set were observed to depolarize in response to NE (see below). Similar electrophysiological difterenees between interneurons located in different strata have been noted in other studies (Kawaguchi and Ilama, 1988; Lacaille and Schwartzkroin, 1988a; Lacaille and Williams, 1990).

\section{Opioid response}

Previous reports have demonstrated that opiate receptors are present on interneurons in the rat hippocampal formation (Crain et al., 1986; McLean et al., 1987). Opioids decrease the firing rate of interneurons (Pang and Rose, 1989) by causing a membrame hyperpolarization (Madison and Nicoll, 19886), but they do not affect the membrane properties of pyramidal cells (Nicoll et al. 
A

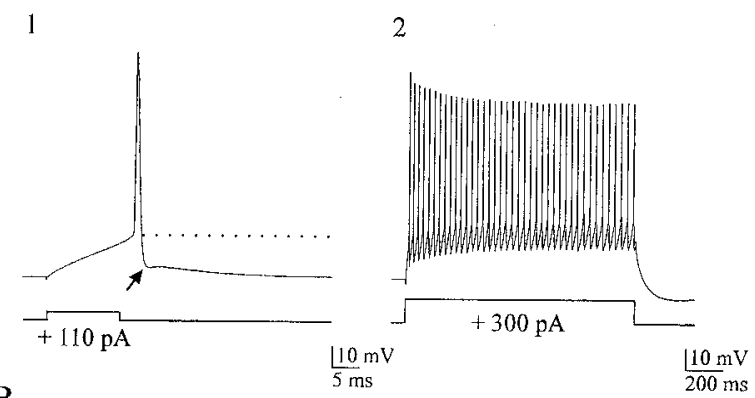

B

1

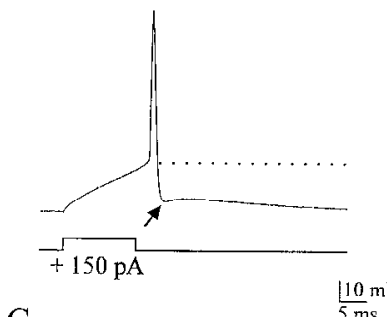

C

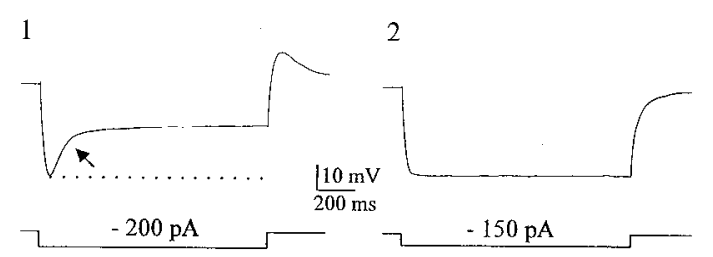

Figure 3. Electrophysiological properties of CA1 interneurons depolarized by adrenergic agonists. $A$, Whole-cell current-clamp recording from an interneuron located in s. oriens. These interneurons exhibited large amplitude, short-duration action potentials that were followed by a rapid afterhyperpolarization (1, arrow) and fired characteristic nonaccommodating trains of action potentials in response to steady depolarizing current injection (2). $B$, Interneurons located in s. radiatum (shown here) and s. lacunosum-moleculare had smaller-amplitude action potentials (1) and typically displayed some spike frequency adaptation with prolonged injection of depolarizing current (2). C, Time-dependent inward rectification was visible in most interneurons when a hyperpolarizing current step was applied $(1$, arrow). However, of those that depolarized in response to adrenergic agonists, $\sim 25 \%$ had no detectable rectification (2). Current steps were elicited from $-65 \mathrm{mV}$ for the time indicated by the bars below each trace. $\left[\mathrm{K}^{+}\right]_{0}=2.5 \mathrm{mM}$.

1980). For this reason, we used the response to the synthetic opioid peptide DALA in initial studies to confirm that these cells were inhibitory interneurons. Application of DALA $(10 \mu \mathrm{M})$ caused a marked hyperpolarization of interneurons from all strata (see Fig. $7 B$ ) and a cessation of spontaneous action potential generation recorded in cell-attached patch recordings $(n=17$; data not shown). This is consistent with previous work showing that DALA decreases the frequency of spontaneous IPSCs recorded from CA1 pyramidal cells (Cohen et al., 1992).

\section{Morphology}

Interneurons have diverse morphologies, with patterns of dendritic and axonal arborizations distinct from pyramidal cells (Ramon y Cajal, 1911; Lorente de No, 1934) (Fig. 4). The interneurons from which we recorded in this study lacked a primary dendritic shaft and, instead, had several highly branched dendrites that often were interrupted along their length by periodic swellings; however, dendritic spines were never observed. Camera lucida reconstructions of Neurobiotin- or biocytin-filled interneurons demonstrate that the dendritic arbors of interneurons located in s. oriens typically consisted of several branches projecting apically toward the hippocampal fissure, as well as a few basal dendrites projecting laterally along s. oriens (Fig. 5). In contrast, the dendrites of interneurons located in s. radiatum and $s$. lacunosum-moleculare typically lacked a consistent orientation but arborized throughout these regions, often traversing the pyramidal cell layer. The axons of interneurons were very fine $(<1$ $\mu \mathrm{m})$ and varicose, with putative axon terminals visible as discrete puncta that often were distributed throughout $\mathrm{s}$. pyramidale (see Fig. 5). Tracer coupling was never observed between interneurons, even when the low molecular weight biotin analog Neurobiotin was used (Vaney, 1991). These morphological characteristics are consistent with those shown for hippocampal CA1 interneurons in previous studies (Ramon y Cajal, 1911; Lorente de No, 1934; Kawaguchi and Hama, 1988; Lacaille and Schwartzkroin, 1988a; Lacaille and Williams, 1990; Buhl et al., 1994a,b; McBain et al., 1994).

We used these multiple criteria (location, electrophysiological properties, opioid response, and morphology) to confirm that the cells used in this study were local-circuit interneurons.

\section{Adrenergic depolarization of interneurons}

To examine the direct effect of adrenergic agonists on hippocampal interneurons, whole-cell current-clamp recordings were made from visually identified interneurons in area CA1. Adrenergic agonists caused one of two responses when applied to interneurons located in different strata: either a slow depolarization or a more rapid hyperpolarization of the membrane potential. The type of response observed was dependent on the location of the interneuron. Virtually all interneurons located in s. oriens slowly depolarized in response to NE or EPI $(10 \mu \mathrm{M})(11.2 \pm 2.9 \mathrm{mV}$, range $6-17 \mathrm{mV} ; n=8 / 9$ ), which often resulted in the spontaneous generation of action potentials (Fig. $6 A$ ); NE elicited no change in the membrane potential of one cell. Most interneurons located in either s. radiatum or s. lacunosum-moleculare also slowly depolarized $(11.4 \pm 5.6 \mathrm{mV}$, range $5-28 \mathrm{mV} ; n=46 / 64)$ when exposed to either NE or EPI, although a significant number hyperpolarized $(\sim 7 \mathrm{mV} ; n=18 / 64)$; biphasic responses were recorded in only two neurons in this study and were excluded from the data set. The ability of NE to depolarize quiescent cells past their threshold for action potential generation provides an explanation for the increase in the amplitude of spontaneous, action potentialdependent IPSCs recorded postsynaptically. An increase in spontaneous EPSPs sometimes was observed in interneurons with NE application (see Fig. 6A), perhaps reflecting the small depolarizing effect of NE on pyramidal neurons (Madison and Nicoll, 1986). To reduce the possibility that the depolarizing action of these adrenergic agonists resulted from the release of another neuroactive substance in the slice, particularly through depolarization of neurons presynaptic to the recorded cell, we applied adrencrgic agonists to interncurons recorded in the presence of TTX, a sodium channel blocker. TTX $(1 \mu \mathrm{M})$ did not prevent the depolarizing response of EPI (see Fig. $7 B$ ), although the magnitude of the response typically was reduced $(6.3 \pm 1.5 \mathrm{mV}$, range $5-9 \mathrm{mV} ; n=6$ ).

The magnitude of the depolarization induced by adrenergic agonists decreased with time during whole-cell recordings, suggesting that dialysis of some intracellular signal component(s) occurred in this configuration. To avoid the complications of whole-cell dialysis, we took advantage of the observation that the 

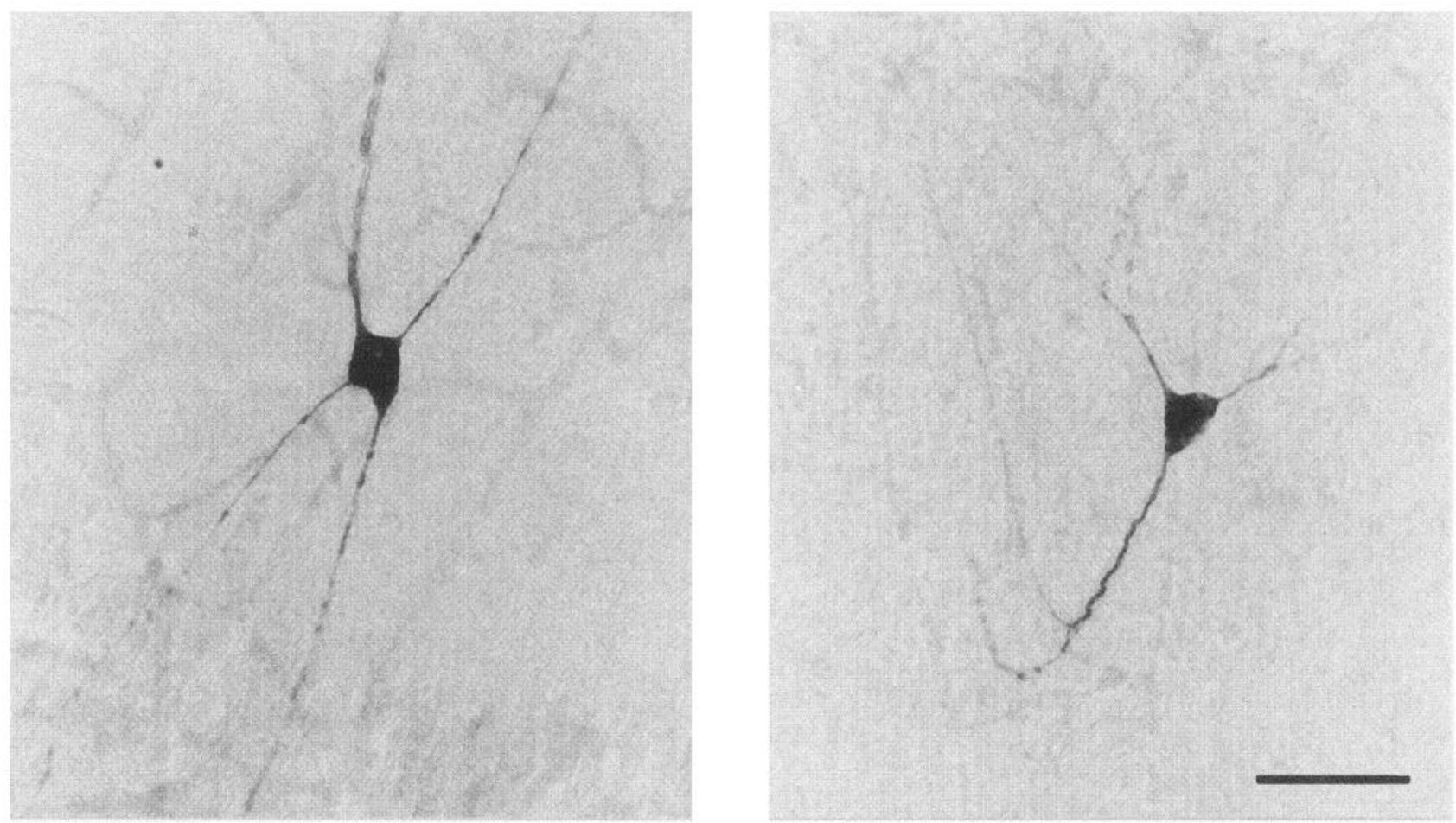

Figure 4. Morphology and location of Neurobiotin-filled interneurons from area CA1. Photomicrographs of interneurons located in s. radiatum (left) and at the border of s. lacunosum-moleculare (right) that were depolarized by NE. These cells had heterogeneous morphologies that were distinct from pyramidal cells. Dye coupling was not observed between interneurons, suggesting that these cells are not coupled via gap junctions. Scale bar, $50 \mu \mathrm{m}$.

resistive and capacitive currents generated by action potentials can be recorded in the cell-attached patch configuration (Fenwick et al., 1982). Cell-attached patch recordings from the somata of visually identified interneurons confirmed the excitatory effects of the adrenoceptor agonists described above. In these experiments, $\left[\mathrm{K}^{+}\right]_{\mathrm{o}}$ was raised to $3.5 \mathrm{~mm}$ to increase the probability that interneurons would be brought to threshold. Bath application of NE or EPI $(10 \mu \mathrm{M})$ caused a significant increase in the firing

\section{SM}

SL

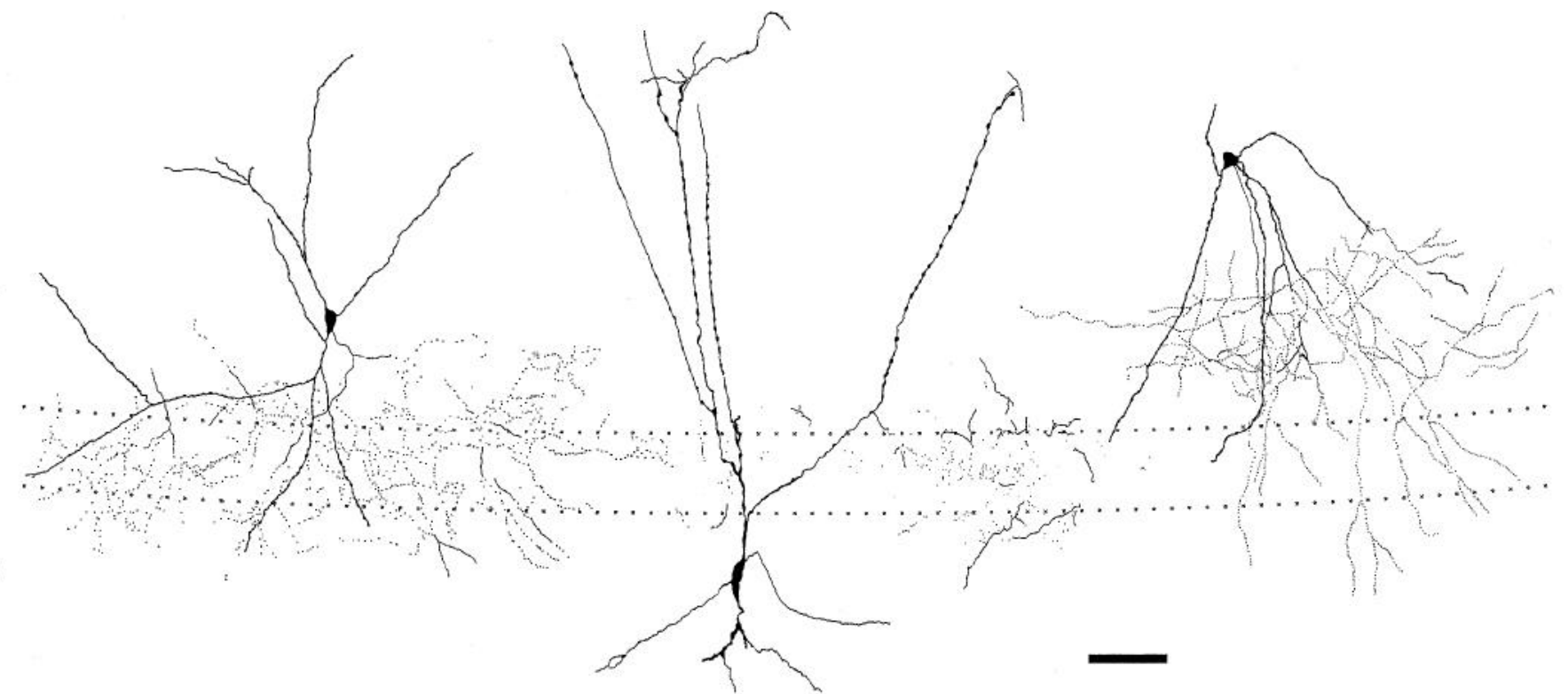

Figure 5. Camera lucida reconstructions of three CA1 interneurons depolarized by NE. Interneurons were recorded using whole-cell electrodes with either biocytin $(0.2 \%$; left and right $)$ or Neurobiotin $(0.2 \%$; middle) included in the normal pipette solution. Interneurons with somata located in s. oriens (middle) typically had several apically projecting dendrites that were varicose and had extensive axonal ramifications that were visible throughout $\mathrm{s}$. pyramidale. Interneurons with somata located in s. radiatum (left and right) had dendrites that projected throughout these regions and often traversed the pyramidal cell layer. The axons of these cells also arborized in s. pyramidale. Scale bar, $100 \mu \mathrm{m}$. $S M$, s. moleculare; $S L$, s. lacunosum; $S R$, s. radiatum; $S P$, s. pyramidale; $S O$, s. oriens; $A$, alveus. 
A

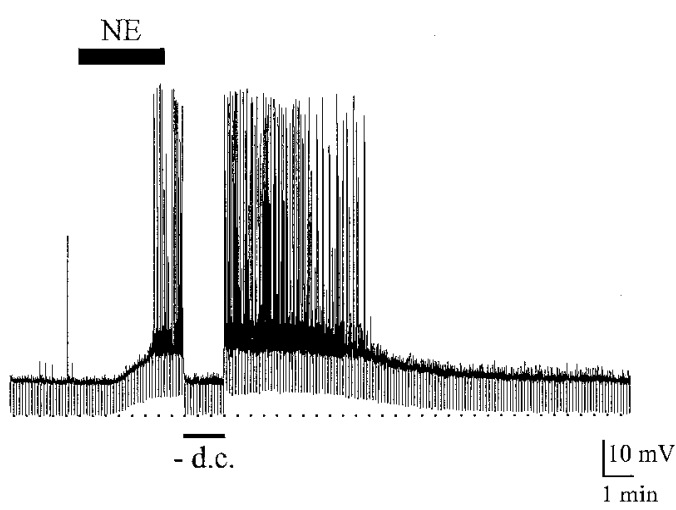

B

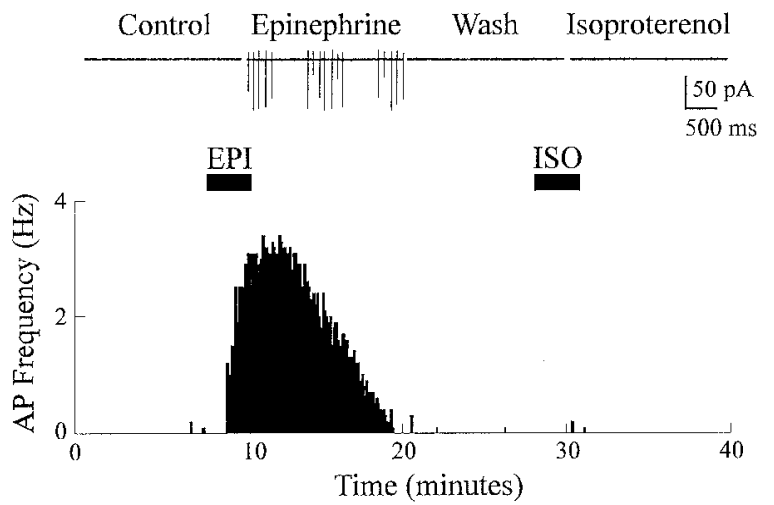

Figure 6. NE and EPI depolarize hippocampal interneurons. $A$, Continuous membrane potential versus time plot for a current-clamp recording from an interneuron located in s. oriens. Bath application of NE $(10 \mu \mathrm{M})$ caused a reversible depolarization of the resting membrane potential of this cell $(N E)$. This depolarization was sufficient to bring the cell to threshold, resulting in spontaneous action potential generation. Repetitive hyperpolarizing current pulses $(-40 \mathrm{pA}, 400 \mathrm{msec}$, every $6 \mathrm{sec})$ were applied continuously during the experiment, and the membrane potential was returned to the resting level with negative current $(-d . c$.$) for the$ period indicated by the bar, demonstrating that the depolarization was associated with little change in input resistance (sce Results). $V_{\mathrm{m}}=-64$ $\mathrm{mV} . B$, Frequency versus time plot for a cell-attached patch recording of action potentials from a visually identified interneuron located in $\mathrm{s}$. radiatum. Bath application of EPI $(10 \mu \mathrm{M})$ for the period indicated by the bar reversibly increased the firing frequency of this interneuron (EPI). Action potentials appeared as bursts of three to eight spikes visible in the raw traces above the plot. In contrast, the $\beta$-adrenoceptor agonist ISO $(10 \mu \mathrm{M})$ did not bring this cell to its firing threshold (ISO). Repeated application of EPI again increased the firing frequency (data not shown). CNQX $(10 \mu \mathrm{M})$ and APV $(50 \mu \mathrm{M})$ were present in the ACSF, and the patch was voltageclamped at $\sim 0 \mathrm{mV}$ (pipette potential $=-60 \mathrm{mV}$ ). The amplitudes of both the intracellular action potentials and the extracellular spikes are attenuated because of the slow sampling frequency $(1.5-3 \mathrm{kHz}) \cdot\left[\mathrm{K}^{+}\right]_{\mathrm{o}}=2.5 \mathrm{~mm}$.

frequency compared with control conditions in 10 of 13 cells (mean $0.9 \mathrm{~Hz}$, range $0-3.6 \mathrm{~Hz}$, control; mean $6.6 \mathrm{~Hz}$, range 3.7-8.5 IIz, NE or EPI; $n=10$; Fig. $6 B$ ); in the remaining threc cells, which were located in either s. lacunosum-moleculare or s. radiatum, application of EPI resulted in a cessation of all spontaneous activity (see above). Both effects were fully reversible with washout of the drug. In the presence of adrenergic agonists, action potentials often were generated in bursts of three to eight spikes (Fig. 6B). This phasic firing behavior of interneurons was also inferred postsynaptically, because oscillations in the frequency of IPSCs recorded from pyramidal cells often were apparent during the application of adrenergic agonists (see Fig. $1 B$ ). However, this
A

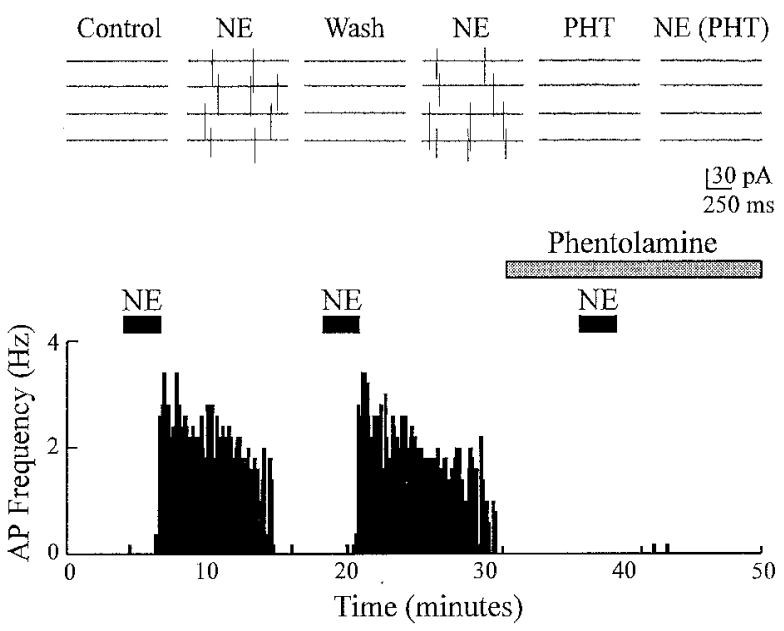

B

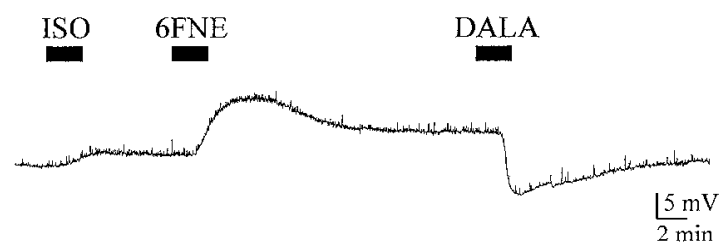

Figure 7. The adrenergic depolarization is mediated by an $\alpha$ adrenoceptor. $A$, Frequency versus time plot of a cell-attached patch recording of action potentials from a visually identified interneuron located in s. oriens. Repeated application of NE $(10 \mu \mathrm{M})$ reversibly increased the firing frequency of this interneuron $(N E)$. The effect of $N E$ was blocked by the application of the selective $\alpha$-adrenoceptor antagonist phentolamine $(P H T ; 1 \mu \mathrm{M})$. The ACSF contained CNQX $(10 \mu \mathrm{M})$ and APV $(50 \mu \mathrm{M})$, and the patch was voltage-clamped at $\sim 0 \mathrm{mV}$ (pipette potential $=-60 \mathrm{mV}$ ). $\left[\mathrm{K}^{+}\right]_{0}=3.5 \mathrm{~mm} . B$, Resting membrane potential versus time plot for a current-clamp recording from an interneuron located in s. oriens. Application of the $\beta$-adrenoceptor agonist ISO $(10 \mu \mathrm{M})$ caused only a slight change in the resting potential of this interneuron (ISO), whereas the selective $\alpha$-adrenoceptor agonist 6FNE $(10 \mu \mathrm{M})$ caused a large depolarization $(6 F N E)$. Application of the synthetic opioid DALA $(10 \mu \mathrm{M})$ resulted in a hyperpolarization, confirming that this cell was an interneuron $(D A L A)$. The ACSF contained TTX $(1 \mu \mathrm{M})$ to block all action potential-mediated release of neurotransmitters. $V_{\mathrm{m}}=-66 \mathrm{mV} \cdot\left[\mathrm{K}^{+}\right]_{\mathrm{o}}=$ $2.5 \mathrm{~mm}$.

oscillatory behavior was not observed in whole-cell recordings from interneurons.

\section{Pharmacology of the depolarization}

Consistent with the pharmacology of the adrenergically mediated increase in the frequency of spontaneous IPSC's recorded from pyramidal cells, the depolarizing action of NE or EPI on interncurons appcars to be mediated by an $\alpha$ adrenoceptor. Cellattached patch recordings of action potentials from visually identified interneurons were used primarily to assay the effects of different adrenergic agonists and antagonists because repeated application of agonists could be made without decrement in the magnitude of the response. Application of the selective $\alpha$ adrenoceptor agonist $6 \mathrm{FNE}(10 \mu \mathrm{M})$ caused a significant increase in the frequency of spontaneous action potential discharge compared with control conditions (mean $1.6 \mathrm{~Hz}$, range $0-3.4 \mathrm{~Hz}$, control; mean $8.6 \mathrm{~Hz}$, range $6.4-10.8 \mathrm{~Hz}, 6 \mathrm{FNE} ; n=7$ ). In 
contrast, the selective $\beta$-adrenoceptor agonist ISO $(10 \mu \mathrm{M}) \mathrm{did}$ not bring quiescent cells to their firing threshold (see Fig. $6 B$ ); however, a small increase in firing frequency often was detected when some spontaneous activity was present (mean $1.5 \mathrm{~Hz}$, range $0-2.7 \mathrm{~Hz}$, control; mean $1.8 \mathrm{~Hz}$, range $0-2.9 \mathrm{~Hz}$, ISO; $n-4$ ). The action of $\mathrm{NE}$ on the firing frequency of interneurons could be blocked by applying the selective $\alpha$-adrenoceptor antagonist phentolamine $(1-10 \mu \mathrm{M} ; n=4$; Fig. $7 A)$ but persisted in the presence of the $\beta$-adrenoceptor antagonist propranolol $(2-10 \mu \mathrm{M}$; $n=5$; data not shown). This pharmacological profile was substantiated further through whole-cell current-clamp recordings made in the presence of TTX $(1 \mu \mathrm{M})$. Bath application of ISO (10 $\mu \mathrm{M})$ caused only a small change in the resting potential of interneurons (mean $1.1 \mathrm{mV}$, range $04 \mathrm{mV} ; n-8$ ), whereas application of $6 \mathrm{FNE}$ or $6 \mathrm{FE}$ at the same concentration $(10 \mu \mathrm{M})$ resulted in a significant depolarization $(8.0 \pm 2.4 \mathrm{mV}$, range $4-12 \mathrm{mV} ; n=$ 10; Fig. 7B).

The subtype of $\alpha$ adrenoceptor responsible for this depolarizing action was also examined via cell-attached patch recordings. Application of the $\alpha$ adrenoceptor agonist 6FNE $(10 \mu \mathrm{M})$ elicited a large increase in the firing frequency of interneurons (mean 1.6 $\mathrm{Hz}$, range $0-3.4 \mathrm{~Hz}$, control; mean $8.6 \mathrm{~Hz}$, range $6.4-10.8 \mathrm{~Hz}$, $6 \mathrm{FNF} ; n=7$ ), consistent with that ohserved in whole-cell recordings. This effect persisted in the presence of the selective $\alpha_{2^{-}}$ adrenoceptor antagonist atipamezole $(1 \mu \mathrm{M})$ (Virtanen et al., 1989) (Fig. $8 A$ ) but could be blocked completely by the application of the selective $\alpha_{1}$-adrenoceptor antagonist YM-12617 (0.5-1 $\mu \mathrm{M} ; n=7$ ) (Honda et al., 1987) (Fig. 8B). In addition, the $\alpha_{1}$-adrenoceptor agonist phenylephrine $(10 \mu \mathrm{M})$ was also able to increase the firing frequency of these cells (mean $1.2 \mathrm{~Hz}$, range 0-3.9 Hz, control; mean $6.3 \mathrm{~Hz}$, range $1.4-12.7 \mathrm{~Hz}$, phenylephrine; $n=5$; data not shown). These results suggest that the depolarizing action of $\mathrm{NE}$ is mediated primarily by an $\alpha_{1}$ adrenoceptor.

\section{Mechanisms underlying the depolarization}

Wholc-cell voltage-clamp recordings werc made from visualized interneurons located in various strata of area CA1 to measure the conductance changes underlying the depolarizing action of adrenergic agonists. The application of the selective $\alpha$-adrenergic agonist $6 \mathrm{FE}(10 \mu \mathrm{M})$ produced an inward current in interneurons that were voltage-clamped at their resting potential $(41 \pm 22 \mathrm{pA}$, range $11-96 \mathrm{pA} ; n=26$ ), whereas the $\beta$-adrenoceptor agonist ISO (10 $\mu \mathrm{M})$ induced little or no current $(2.9 \pm 1.7 \mathrm{pA}$, range $1.5-5.4 \mathrm{pA}$; $n=5$ ). To examine whether this inward current was associated with a conductance increase or decrease, we measured either the amplitude of repetitive hyperpolarizing current steps in currentclamp (using a -DC offset to return the cell to the control potential during the peak of the response) or the current response to repetitive hyperpolarizing voltage steps in cells voltageclamped at their resting potential. In most cells, the application of $\mathrm{NE}$ resulted in little change in input resistance (see Fig. 6A), suggesting that NE may induce a simultaneous increase in one conductance and a decrease in a second conductance (Brown et al., 1971; Alreja and Aghajanian, 1993). In many interneurons, a slowly activating inward current was visible during hyperpolarizing voltage steps, with properties similar to $I_{\mathrm{h}}$ (see Fig. 9A2) (Mayer and Westbrook, 1983; McCormick and Pape, 1990a; Banks et al., 1993; Solomon and Nerbonne, 1993). In cells that lacked $I_{\mathrm{h}}$, the NE-induced inward current typically was associated with a small increase in input resistance ( $n=11 / 14$; Fig. $9 A 1)$. This increase in input resistance was visible as a decrease in the amplitude of the
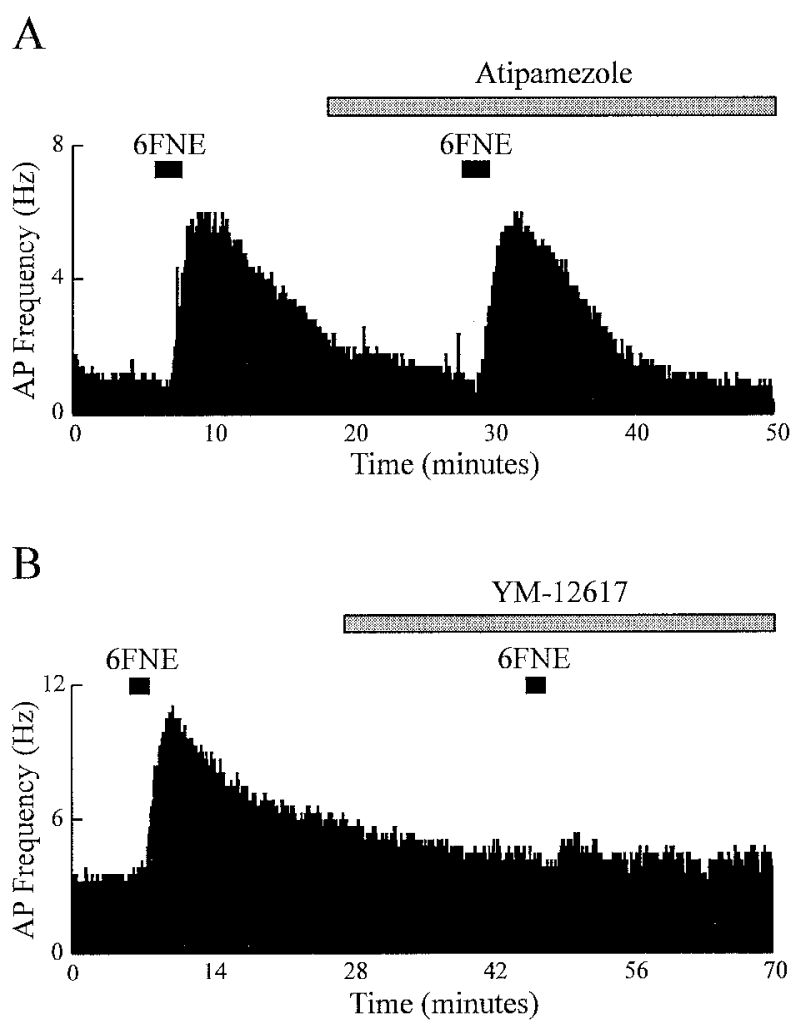

Figure 8. Effects of selective $\alpha_{1}$ - and $\alpha_{2}$-adrenoceptor antagonists on the increase in firing frequency produced by $6 \mathrm{FNE}$. $A$, Frequency versus time plots of action potential frequency from a cell-attached patch recording made from a visually identified s. oriens interneuron. Bath application of $6 \mathrm{FNE}(10 \mu \mathrm{M})$, for the period indicated by the bar ( $6 F N E)$, caused a reversible increase in the firing frequency that was not prevented by bathing the slice in the selective $\alpha_{2}$ antagonist atipamezole $(1 \mu \mathrm{M}) . B$, In contrast, the effect of $6 \mathrm{FNE}(10 \mu \mathrm{M})$ was blocked in a second s. oriens interneuron by the application of the selective $\alpha_{1}$ antagonist YM-12617 (1. $\mu \mathrm{M})$. In both experiments, the $\left[\mathrm{K}^{+}\right]_{0}$ was $3.5 \mathrm{~mm}$ and the patch potential was $\sim 0 \mathrm{mV}$ (pipette potential $=-65 \mathrm{mV}$ ).

whole-cell current in response to a voltage step of constant size (Fig. 9A2). Alternatively, in cells that displayed a prominent $I_{\mathrm{h}}$, the NE-induced current was associated with a decrease in input resistance $(n=16 / 16)$ reflected by an increase in the size of the current response to hyperpolarizing voltage steps (Fig. 9B1,B2). In these interneurons, the amplitude of the current measured al the end of a $500 \mathrm{msec}$ hyperpolarizing step increased more than the instantaneous current (Fig. 9B1,B2), suggesting that a modulation of $I_{\mathrm{h}}$ accounts for this decrease in input resistance.

The previous results suggest that NE has opposite effects on two conductances in hippocampal interneurons, increasing $I_{\mathrm{h}}$ but decreasing a second conductance. To examine these conductance changes in more detail, slow (10 sec long) depolarizing voltage ramps $(-130$ to $-60 \mathrm{mV})$ were performed in voltage-clamped interneurons. NE has been shown to increase $I_{\mathrm{h}}$ in other neurons through activation of $\beta$ adrenoceptors (McCormick and Pape, 1990b); however, our results suggest that the excitatory action of $\mathrm{NE}$ is mediated primarily by an $\alpha_{1}$ adrenoceptor. Therefore, antagonists selective for $\alpha_{1}$ and $\beta$ adrenoceptors were used to isolate the effect of NE on each conductance. The current-voltage relationship of the NE-induced current measured in the presence of the $\beta$-adrenoceptor antagonist propranolol $(1-5 \mu \mathrm{M})$ revealed a current that was inward at the resting potential $(-65 \mathrm{mV})$ but that reversed and became outward at approximately $-95 \mathrm{mV}(-96 \pm$ 


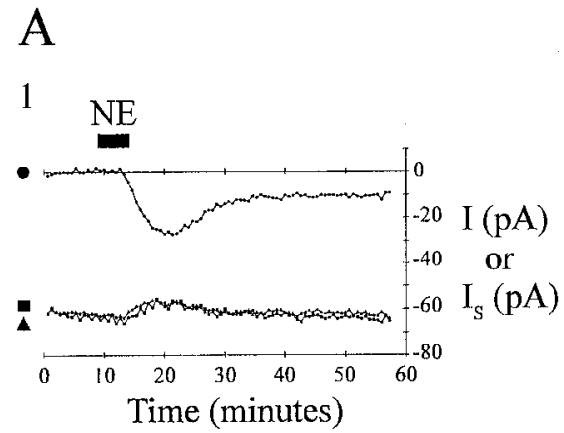

B

1
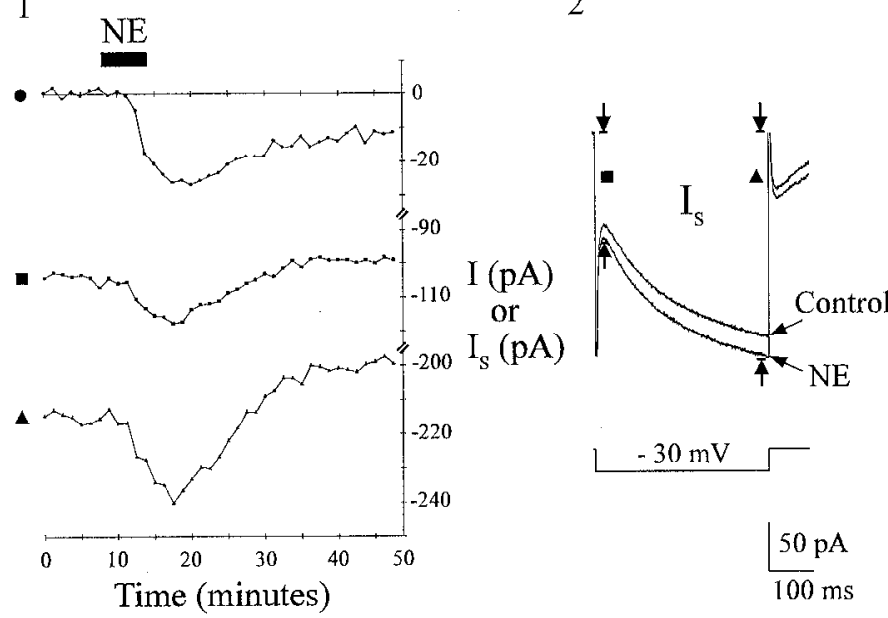

Figure 9. Input resistance changes caused by $\alpha$-adrenoceptor agonists. $A$, A small s. oriens interneuron that lacked time-dependent rectification (2) was voltage-clamped at its resting potential $\left(V_{\mathrm{m}}=-64 \mathrm{mV}\right)$, and repetitive hyperpolarizing steps $(-30 \mathrm{mV}, 500 \mathrm{msec}$, every $40 \mathrm{sec})$ were applied. Bath application of NE $(20 \mu \mathrm{M})$ for the period indicated by the bar resulted in an inward current $(1,0)$ that was accompanied by a small change in input resistance, as indicated by the decrease in amplitude of the response to the hyperpolarizing voltage steps $(1,2, \mathbf{G}, \mathbf{A})$. Normalized current traces from the experiment (1) are superimposed (2) to show the decrease in amplitude. $B$, A large s. oriens interneuron with detectable $I_{\mathrm{h}}$ (visible as the slowly activating inward current during the step hyperpolarization in 2) was voltage-clamped at the resting potential $\left(V_{\mathrm{m}}=-60\right.$ $\mathrm{mV}$ ), and repetitive hyperpolarizing steps $(-30 \mathrm{mV}, 500 \mathrm{msec}$, every 2 min) were applied. Bath application of NE $(20 \mu \mathrm{M})$ for the period indicated by the bar resulted in an inward current $(l, 0)$ that was associated with a decrease in input resistance, visible as an increase in the amplitude of the current response to the hyperpolarizing voltage steps $(l$, 口, A). Normalized current traces from the experiment are superimposed (2) to show that the amplitude of the current at the end of the step $(2, \mathbf{\Delta})$ increased more than the instantaneous current $(2, \mathbf{D})$, suggesting that $I_{\mathrm{h}}$ is potentiated by NE in these interneurons. The $\Lambda \mathrm{CSF}$ in these experiments contained TTX $(1 \mu \mathrm{M})$. Illustrated traces are averages of three consecutive responses.

$4 \mathrm{mV} ; n=6$ ), near the $\mathrm{K}^{+}$reversal potential predicted by the Nernst equation ( $94.4 \mathrm{mV}$; Fig. 10A). The reversal potential of this current was not affected by replacing gluconate with $\mathrm{Cl}^{-}$as the internal anion ( $-97 \pm 6 \mathrm{mV} ; n=8)$, suggesting that $\mathrm{Cl}^{-}$is not a prominent carrier for this current. These results suggest that the $\alpha$ adrenoceptor-dependent inward current results from the decrease in $\mathrm{K}^{+}$conductance and is consistent with the increase in input resistance seen in cells lacking time-dependent inward rectification. In contrast, the shift in the current-voltage relationship produced by NE in the presence of the $\alpha_{1}$-adrenoceptor antagonist YM-12617 $(0.5-1 \mu \mathrm{M})$ in cells showing inward rectification did not reverse over the voltage range tested $(-130$ to $-60 \mathrm{mV} ; n=$ 9). NE produced little current at the resting potential (Fig. 10B), similar to that observed for ISO alone, although a prominent inwardly rectifying current appeared at potentials negative to approximately $-70 \mathrm{mV}$; ISO elicited a similar current in YM$12617(n=2)$. These characteristics are similar to those reported for $I_{1}$ (Pape and McCormick, 1989) and suggest that NE can increase $I_{\mathrm{h}}$ in some interneurons through the activation of $\beta$ adrenoceptors.

The primary mechanism for the depolarizing action of $\mathrm{NE}$ appears to be the $\alpha$ adrenoceptor-dependent modulation of resting $\mathrm{K}^{+}$conductance, because interneurons that lacked timedependent inward rectification and $I_{\mathrm{h}}$ (see Figs. $6 B 1,9 A 2$ ) still depolarized in response to $\mathrm{NE}$ and displayed an inward current without recruitment of $I_{\mathrm{h}}$ (Fig. 9A1,A2). In addition, adding cesium $(\mathrm{CsCl}, 2-3 \mathrm{mM})$ to the superfusing ACSF blocked timedependent inward rectification and $I_{\mathrm{h}}$ (Fig. 11 $A 1, A 2$ ) but did not block the depolarizing action of $\alpha$-adrenoceptor agonists (8.1 \pm $2.9 \mathrm{mV}$, range $3-15 \mathrm{mV}, 6 \mathrm{FNE} ; n=16$; Fig. $11 B$ ) or the inward current recorded in voltage-clamped interneurons $(21.3 \pm 11.7$ $\mathrm{pA}$, range 6.8-39.1 pA, 6FNE; $n=6$ ). However, with prolonged application cesium alone caused cells to depolarize. In cellattached patch recordings from visualized interneurons, the increase in firing frequency produced by $6 \mathrm{FNE}$ also was not blocked by external cesium ( $n=3$; Fig. $12 A$ ). These findings were substantiated further via whole-cell recordings from CA1 pyramidal neurons; because the large 6FNE-induced increase in the frequency of spontaneous monosynaptic IPSCs recorded from these cells was not blocked by extracellular cesium ( $n=4$; Fig. 12B), even though cesium alone often induced a small increase in the frequency of these events.

\section{DISCUSSION}

$\mathrm{NE}$ and EPI cause an increase in tonic inhibition in the in vitro hippocampal slice, visible as an increase in both the frequency and amplitude of spontaneously occurring IPSPs in CA1 pyramidal cells (Madison and Nicoll, 1988a). Several lines of evidence in this paper and presented previously suggest that this increase results from a direct excitatory action on inhibitory interneurons. In particular, adrenergic agonists still are able to elicit this response when interneurons are uncoupled from their glutaminergic excitatory inputs (Doze et al., 1991), suggesting that the increase in IPSPs is not secondary to an increase in excitability of neurons presynaptic to the GABA-releasing interneurons. Moreover, adrenergic agonists do not affect either the frequency or the amplitude of miniature IPSCs, demonstrating that the increase in average IPSC amplitude results from an increase in the action potential-dependent release of GABA and not from a change in postsynaptic sensitivity to synaptically released GABA. We confirmed that NE causes interneurons to depolarize and increase their firing rate via both whole-cell and cell-attached patch recordings from visualized interneurons located in the different strata of area CA1.

$\alpha$-Adrenoceptor-mediated postsynaptic responses have been demonstrated in other areas of the CNS, including the cerebral cortex (Bevan et al., 1977), thalamus (McCormick and Prince, 1988), hypothalamus (Randle et al., 1986), reticular formation (Gerber et al., 1990), and dorsal raphe (Pan et al., 1994). In these systems, stimulation of $\alpha_{1}$ adrenoceptors has been shown to cause a depolarization through an inhibition of a resting (lcak) $\mathrm{K}^{+}$ current, termed $I_{\mathrm{KL}}$ (for review, see Nicoll et al., 1990) (Aghajanian, 1985; Stevens et al., 1994). The results presented in this 
A
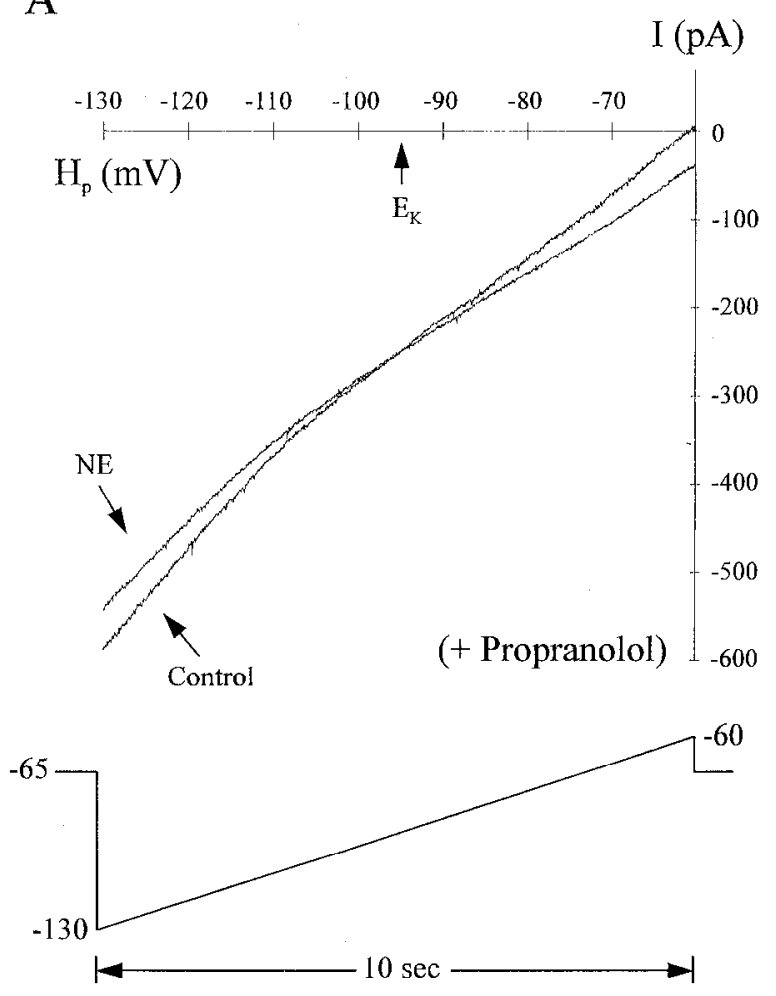

B
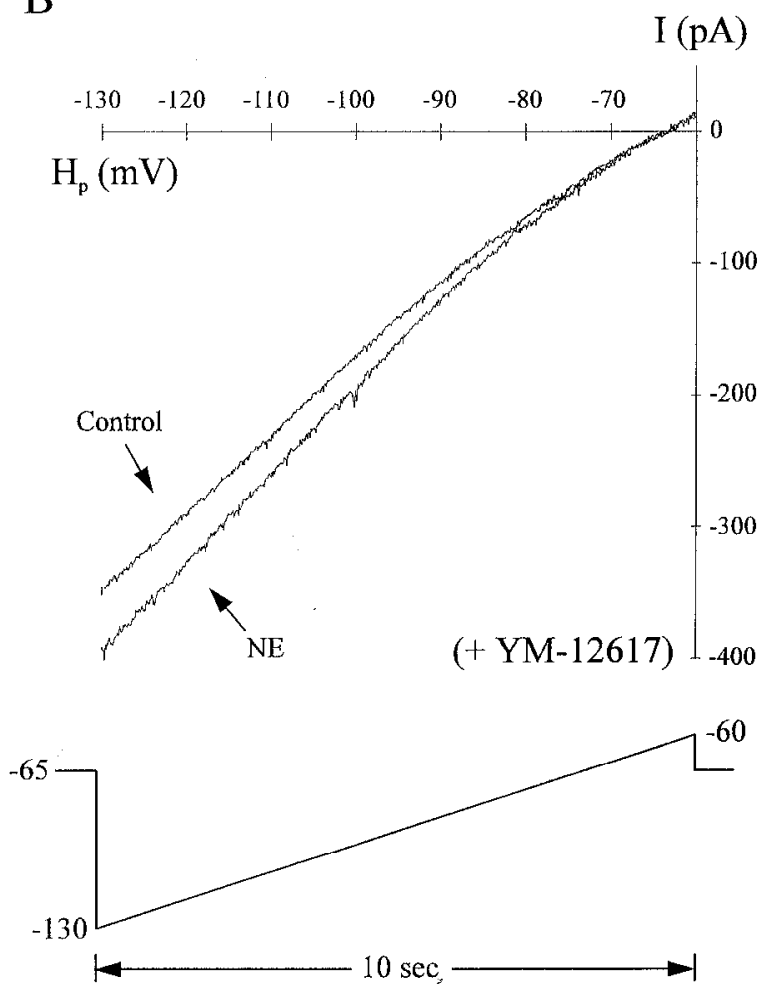

Figure 10. Reversal potentials of the NE-induced currents. Slow $(10 \mathrm{sec})$ voltage ramps $(-130$ to $-60 \mathrm{mV})$ were applied to interneurons under control conditions and in the presence of NE $(20 \mu \mathrm{M}) . A$, In the presence of the selective $\beta$-adrenoceptor antagonist propranolol $(1 \mu \mathrm{M})$, NE induced an inward current at the resting potential $\left(V_{\mathrm{m}}--65 \mathrm{mV}\right)$ that reversed and became outward at approximately $-95 \mathrm{mV}$, near the calculated $\mathrm{K}^{+}$equilibrium potential $(-94.4 \mathrm{mV})$. This response was recorded with a $\mathrm{KCl}$-based internal solution. $B$, In the presence of the $\alpha_{1}$-adrenoceptor antagonist YM-12617 $(1 \mu \mathrm{M}), \mathrm{NE}$ produced no change in holding current at the resting potential, but an inward current became visible at potentials negative to approximately $-70 \mathrm{mV}$ that displayed prominent inward rectification. The ACSF in these experiments contained TTX $(1 \mu \mathrm{M}), \mathrm{CNQX}(10 \mu \mathrm{M}), \mathrm{APV}(50 \mu \mathrm{M})$, and picrotoxin $(50 \mu \mathrm{M}) .\left[\mathrm{K}^{+}\right]_{\mathrm{o}}=2.5 \mathrm{~mm}$.

paper suggest that the slow depolarizing action of NE observed in a subset of hippocampal interneurons occurs through a similar decrease of a resting $\mathrm{K}^{+}$conductance. In addition, an NEdependent increase in the amplitude of $I_{\mathrm{h}}$ was detected in those interneurons that had appreciable $I_{\mathrm{h}}$. This action of NE appears to be mediated by a $\beta$ adrenoceptor, similar to that shown in other systems (Pape and McCormick, 1989; Banks et al., 1993). However, the potentiation of $I_{\mathrm{h}}$ is not necessary to account for the depolarizing action of NE because ISO, a $\beta$-adrenoceptor agonist, produced only a small membrane depolarization $(1-4 \mathrm{mV})$, NE depolarized cells even when $I_{\mathrm{h}}$ was blocked with extracellular cesium, and interneurons that displayed no time-dependent inward rectification still were depolarized by NE. This conclusion was substantiated via recordings of spontaneous monosynaptic IPSCs in CA1 pyramidal neurons, demonstrating that ISO produced only a small increase in the frequency of IPSCs. Furthermore, the large increase in IPSC frequency produced by $\alpha$-adrenoceptor agonists was not blocked by extracellular cesium. These data are consistent with previous studies in thalamic neurons, in which a $\beta$ adrenoceptor-dependent increase in the amplitude of $I_{\mathrm{h}}$ resulted in only a small depolarization of $2-3 \mathrm{mV}$, despite inducing a $>25 \%$ decrease in input resistance (Pape and McCormick, 1989).

\section{Pharmacology of the noradrenergic depolarization}

The NE-induced excitation of hippocampal interneurons was mimicked by an $\alpha_{1}$-adrenoceptor agonist (phenylephrine), persisted in the presence of an $\alpha_{2}$-adrenoceptor antagonist (atipam- ezole), and could be blocked by a selective $\alpha_{1}$-adrenoceptor antagonist (YM-12617), suggesting that this response is mediated primarily by an $\alpha_{1}$ adrenoceptor. Radiolabeled forms of selective agonists and antagonists of $\alpha_{1}$ adrenoceptors (e.g., $\left[{ }^{3} \mathrm{H}\right]$ prazosin, $\left[{ }^{3} \mathrm{H}\right] \mathrm{HEAT}$, and $\left.\left[{ }^{3} \mathrm{H}\right] \mathrm{WB} 4101\right)$ have been used to infer their density and distribution in the hippocampus (for review, see Unnerstall and Kuhar, 1988). In rat hippocampus, only low levels of binding of these agents have been detected, and autoradiographic analysis has demonstrated a relatively homogeneous distribution of binding sites, although a slight enrichment in s. lacunosum-moleculare has been reported (Zilles et al., 1991). However, a high density of binding sites also was detected in the polymorph layer of the dentate gyrus (Zilles et al., 1991), an area known to be enriched in GABAergic neurons (Woodson et al., 1989). The low level of binding observed in area CA1 may reflect the low density of interneurons compared with principal cells (Olbrich and Braak, 1985).

Recent molecular cloning studies have demonstrated the existence of three genes encoding distinct $\alpha_{1}$ adrenoceptors $\left(\alpha_{1 \mathrm{D}}\right)$ $\alpha_{1 \mathrm{~A} / \mathrm{D}}, \alpha_{1 \mathrm{~B}}, \alpha_{1 \mathrm{C}} / \alpha_{1 \mathrm{~A}}$ ) (for review, see Ford et al., 1994). In situ hybridization studies using subtype-specific DNA probes have detected the expression of mRNA encoding $\alpha_{1 \mathrm{D}}\left(\alpha_{1 \mathrm{~A} / \mathrm{D}}\right)$ adrenoceptors in areas of the CNS (e.g., thalamus) in which NE has been shown to depolarize neurons though a decrease in a resting $\mathrm{K}^{+}$ conductance (McCormick and Prince, 1988; Pieribone et al., 1994). However, in the hippocampus, mRNA encoding this receptor was detected in pyramidal neurons but not interneurons 
A

1

\section{2}
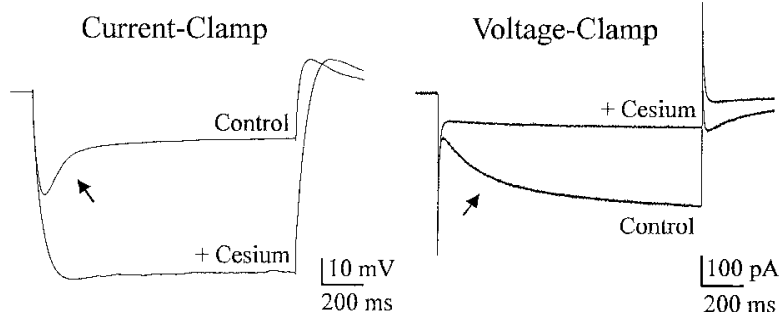
$-200 \mathrm{pA}$
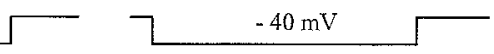

B

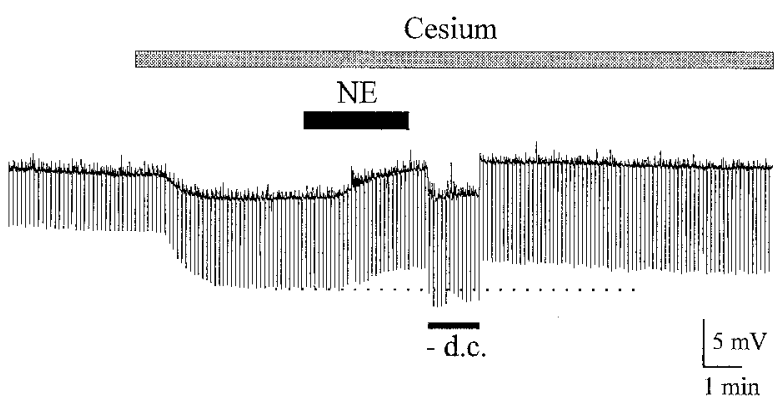

Figure 11. NE can excite interneurons independent of $I_{\mathrm{h}}$ modulation. $A$ : 1 , Whole-cell current-clamp recording from an s. radiatum interneuron demonstrating that extracellular cesium $(2 \mathrm{mM} \mathrm{CsCl} ; 5 \mathrm{~min})$ blocks the time-dependent inward rectification elicited by a constant-current hyperpolarizing step from the resting potential $\left(V_{\mathrm{m}}=-64 \mathrm{mV}\right)$. 2, In vollageclamp, this block of rectification was visible as a reduction in the slowly activating inward current, or $I_{\mathrm{h}}$, elicited by a $-40 \mathrm{mV}$ voltage step from the resting potential $\left(H_{\mathrm{p}}=-64 \mathrm{mV}\right)$. The ACSF contained 'T'IX $(1 \mu \mathrm{M})$, CNQX $(10 \mu \mathrm{M})$, APV $(50 \mu \mathrm{M})$, and picrotoxin $(50 \mu \mathrm{M}) . B$, Continuous record of membrane potential from an interneuron located in s. oriens. Repetitive hyperpolarizing current steps $(-30 \mathrm{pA}, 400 \mathrm{msec}$, every $6 \mathrm{sec})$, visible as downward deflections, were applied to test for changes in input resistance. Application of cesium ( $2 \mathrm{mM} \mathrm{CsCl}$ ) caused a hyperpolarization and an increase in input resistance but did not prevent the depolarizing effect of NE $(20 \mu \mathrm{M}) . V_{\mathrm{m}}=-62 \mathrm{mV}$. The ACSF contained TTX $(1 \mu \mathrm{M})$. $\left[\mathrm{K}^{+}\right]_{0}-2.5 \mathrm{~mm}$.

(Pieribone et al., 1994). The significance of the lack of $\alpha_{1 \mathrm{D}}$ $\left(\alpha_{1 \mathrm{~A} / \mathrm{D}}\right)$-adrenoceptor mRNA in hippocampal interneurons is uncertain, because the cellular distribution of mRNA encoding the prototypical $\alpha_{1 \mathrm{~A}}\left(\alpha_{1 \mathrm{C}}\right)$ adrenoceptor has not yet been examined.

\section{Implications for noradrenergic regulation of pyramidal cell excitability}

Noradrenergic fibers originating in the locus ceruleus provide a dense innervation of the hippocampal formation, where the average density of NE-containing terminals has been estimated at $>2,000,000$ varicosities $/ \mathrm{mm}^{3}$, a density 2- to 10 -fold higher than that found in the neocortex (Oleskevich et al., 1989). Numerous studies have demonstrated that a large proportion of these terminals synapse onto GABAergic perikarya and dendrites (Frotscher and Leranth, 1988; Milner and Bacon, 1989b). However, in vitro studies have demonstrated almost exclusively excitatory effects of NE on principal neurons, including a small depolarization of the membrane potential, an enhancement of voltagegated calcium currents, and a block of the $\mathrm{Ca}^{2+}$-activated $\mathrm{K}^{+}$
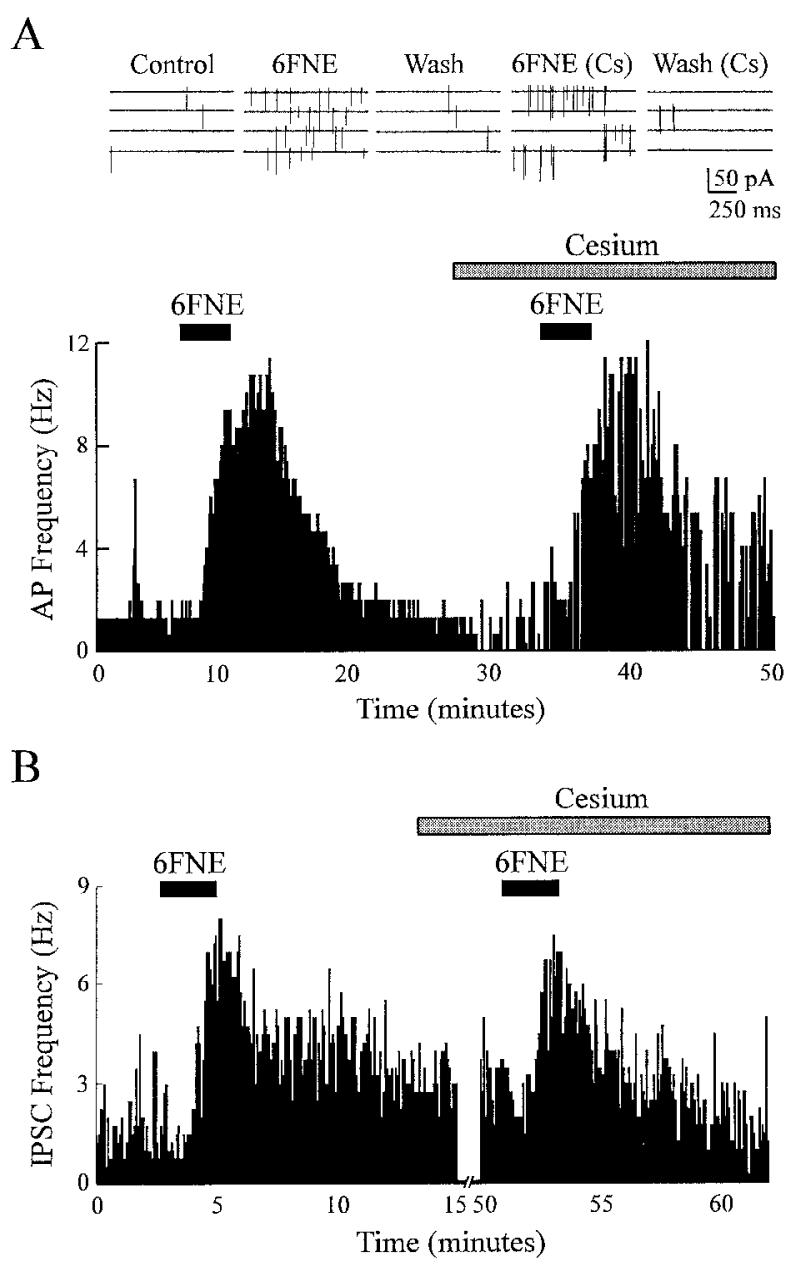

Figure 12. $\alpha$-Adrenoceptor agonists increase the firing frequency of interneurons and increase the frequency of spontaneous IPSCs in pyramidal cells when $I_{\mathrm{h}}$ is blocked. $A$, Cell-attached patch recording of extracellular action potentials from an interneuron located in s. oriens. Top, Sample traces of consecutive sweeps taken during the manipulations displayed in the frequency histogram on the right. Bath application of the $\alpha$-adrenoceptor agonist $6 \mathrm{FNE}(10 \mu \mathrm{M})$ caused a reversible increase in firing frequency that was not blocked by the application of cesium $(3 \mathrm{~mm}$ $\mathrm{CsCl}$ ). In the presence of cesium, action potentials were generated as doublets, in bursts of 10-18 spikes, causing the frequency histogram to appear discontinuous. Spike amplitudes are underestimated because of the slow sampling frequency $(2 \mathrm{kHz})$. Bottom, Frequency versus time plot for the entire experiment demonstrating that $6 \mathrm{FNE}$ reversibly increases the firing frequency in control conditions and in the presence of cesium. The frequency histogram appears discontinuous because of the bursting behavior of this cell when cesium is added to the ACSF. Bins represent the average frequency in three consecutive sweeps. The patch potential was $\sim 0 \mathrm{mV}$ (pipette potential $=-57 \mathrm{mV}$ ). $B$, Frequency versus time plot of spontaneous IPSCs recorded from a CA1 pyramidal neuron. Repeated application of 6FNE $(10 \mu \mathrm{M})$ caused an increase in the IPSC frequency even after prolonged exposure to extracellular cesium $(2 \mathrm{~mm} \mathrm{CsCl})$. In both experiments, the $\left[\mathrm{K}^{+}\right]_{\mathrm{o}}$ was $5 \mathrm{~mm}$ and the ACSF contained CNQX $(10 \mu \mathrm{M})$ and APV $(50 \mu \mathrm{M})$.

current, which results in a reduction in action potential frequency accommodation (for review, see Nicoll et al., 1990). In addition, NE causes an increase in the evoked population response (Mueller et al., 1981) as well as disinhibition (Madison and Nicoll, 1988a) in hippocampal slices. In contrast, data collected in vivo support a general inhibitory role for NE in the hippocampus.

Neurons throughout the CNS receive constant inhibitory input, which is critically important for regulating their level of excitabil- 
ity (Zieglgansberger et al., 1979; Schwartzkroin and Prince, 1980; Johnson and North, 1992; Soltesz and Mody, 1994). The frequency and amplitude of these spontaneous IPSPs serve as an indirect measure of the level of activity of surrounding interneurons (Alger and Nicoll, 1980). Agents that hyperpolarize interneurons lead to a decrease in the frequency and amplitude of IPSPs in their target neurons, causing an increase in excitability through disinhibition (Zieglgansberger et al., 1979; Johnson and North, 1992). Numerous studies have demonstrated that NE causes a reduction in the firing frequency of CA1 pyramidal neurons in vivo (Segal and Bloom, 1974a; Mueller et al., 1982; Pang and Rosc, 1987; Curet and de Montigny, 1988a), although $\mathrm{NE}$ produces only small, inconsistent changes in the membrane potential of pyramidal cells (Madison and Nicoll, 1986). The NE-induced increase in the firing frequency of inhibitory interneurons in the hippocampus, and the resulting increase in both the frequency and amplitude of IPSPs in their target cells, may account for the decrease in spontaneous activity of pyramidal neurons observed in vivo.

The noradrenergic system also has been shown to be potently antiepileptogenic in vivo. Pharmacological perturbations that increase the CNS level of NE, such as L-dopa and/or monamine oxidase inhibitors, elevate seizure thresholds, whereas those that decrease the level of NE, by inhibiting its synthesis (e.g., $\alpha$-methyl$p$-tyrosine), release (e.g., guanethidine), or storage (e.g., reserpine), reduced the threshold for seizures (for review, see Chauvel and Trottier, 1986). In addition, stimulation of the locus ceruleus increases the threshold for kindling-induced scizurcs (Weiss et al., 1990) and suppresses pharmacologically induced epileptiform activity in vivo (Neuman, 1986), as does the direct injection of $\alpha$-adrenoceptor agonists (McIntyre and Guigno, 1988) or grafts of fetal locus ceruleus tissue (Barry et al., 1987). Conversely, destroying NE-containing nerve terminals directly with 6-hydroxydopamine facilitates kindling (Kokaia et al., 1989). $\alpha$-Adrenoceptor agonists also have been reported to be antiepileptogenic in several genetic and lesion-induced models of epilepsy, and abnormalities in the noradrenergic system have been observed in several of these same models (for review, see Chauvel and Trottier, 1986).

Experiments with in vitro models of the epileptic hippocampus provide additional evidence that these inhibitory effects are intrinsic to the hippocampus, because NE blocks spontaneous interictal discharges induced pharmacologically in hippocampal slices (Mueller and Dunwiddie, 1983). However, the extensive nature of the noradrenergic projection and the complexity of the intact hippocampus have made mechanistic interpretations of these antiepileptic effects difficult. The excitatory action of $\alpha$-adrenergic agonists on hippocampal interneurons reported here, and recent results demonstrating that $\alpha$ adrenoceptors reduce evoked release from the excitatory terminals of both mossy fiber and CA3 pyramidal cell recurrent collaterals in hippocampal organotypic cultures (Scanziani et al., 1993), is likely to contribute to these antiepileptic actions. The data presented here suggest an important role for the central noradrenergic system in regulating the level of inhibition in the hippocampus, and this may provide a powerful way to decrease the excitability of pyramidal neurons in vivo pharmacologically.

\section{REFERENCES}

Adejare A, Gusovsky F, Padgett W, Creveling CR, Daly JW, Kirk KI (1988) Synthesis and adrenergic activities of ring-fluorinated epinephrines. J Med Chem 31:1972-1977.
Aghajanian GK (1985) Modulation of a transient outward current in serotonergic neurones by $\alpha_{1}$-adrenoceptors. Nature 315:501-503.

Alger BE, Nicoll RA (1980) Spontaneous inhibitory post-synaptic potentials in hippocampus: mechanism for tonic inhibition. Brain Res 200:195-200.

Alreja M, Aghajanian GK (1993) Opiates surpress a resting sodiumdependent inward current and activate an outward potassium current in locus coeruleus neurons. J Neurosci 13:3525-3532.

Andersen P, Eccles JC, Loyning Y (1964) Pathway of postsynaptic inhibition in the hippocampus. J Neurophysiol 27:592-607.

Babb TL, Pretorius JK, Kupfer WR, Brown WJ (1988) Distribution of glutamate-decarboxylase-immunoreactive neurons in the rat hippocampal formation: light and electron microscopy. J Comp Neurol 278:121-138.

Banks MI, Pearce RA, Smith PH (1993) Hyperpolarization-activated cation current $\left(I_{\mathrm{h}}\right)$ in neurons of the medial nucleus of the trapezoid body: vollage-clamp analysis and enhancement by norepinephrine and cAMP suggest a modulatory mechanism in the auditory brain stem. $\mathbf{J}$ Neurophysiol 70:1420-1432.

Barry DI, Kikvadze I, Brundin P, Bolwig TG, Bjorklund A, Lindvall O (1987) Grafted noradrenergic neurons suppress seizure development in kindling-induced epilepsy. Proc Natl Acad Sci USA 84:8712-8715.

Bevan P, Bradshaw CM, Szabadi E (1977) The pharmacology of adrenergic neuronal responses in the cerebral cortex: evidence for excitatory $\alpha^{-}$and inhibitory $\beta$ receptors. Br J Pharmacol 59:635-641.

Blanton MG, Lo Turco JJ, Kreigstein AR (1989) Whole-cell recording from neurons in slices of reptilian and mammalian cerebral cortex. J Neurosci Methods 30:203-210.

Brown JE, Muller KJ, Murray G (1971) Reversal potential for an clectrophysiological event generated by conductance changes: mathematical analysis (Abstr). Science 174:318A.

Buhl EH, Halasy K, Somogyi P (1994a) Diverse sources of hippocampal unitary inhibitory postsynaptic potentials and the number of release sites. Nature 368:823-828.

Buhl EH, Han ZS, Lorinczi Z, Stezhka VV, Karnup SV, Somogyi P (1994b) Physiological properties of anatomically identified axo-axonic cells in the rat hippocampus. J Neurophysiol 71:1289-1307.

Cantacuzene D, Kirk KL, McCulloh DH, Creveling CR (1979) Effects of fluorine substitution on the agonist specificity of norepinephrine. Science 204:1217-1219.

Chauvel P, Trottier S (1986) Role of noradrenergic ascending system in extinction of epileptic phenomena. Adv Neurol 44:475-487.

Cohen GA, Doze VA, Madison DV (1992) Opioid inhibition of GABA release from presynaptic terminals of rat hippocampal interneurons. Neuron 9:325-335.

Crain BJ, Chank KL, McNamara JO (1986) Quantitative autoradiographic analysis of mu and delta opioid binding sites in the rat hippocampal formation. J Comp Neurol 46:170-180.

Curet O, de Montigny C (1988a) Electrophysiological characterization of adrenoceptors in the rat dorsal hippocampus. I. Receptors mediating the effect of microiontophoretically applied norepinephrine. Brain Res 475:35-46.

Curet O, de Montigny C (1988b) Electrophysiological characterization of adrenoceptors in the rat dorsal hippocampus. II. Receptors mediating the effect of synaptically released norepinephrine. Brain Res 475:47-57.

Dodt HU, Zieglgansberger W (1990) Visualizing unstained neurons in living brain slices by infrared DIC-videomicroscopy. Brain Res 537:333-336.

Doze VA, Bergles DE, Smith SJ, Madison DV (1993) Adrenergic excitation of hippocampal interneurons. Soc Neurosci Abstr 19:1518.

Doze VA, Cohen GA, Madison DV (1991) Synaptic localization of adrenergic disinhibition in the rat hippocampus. Neuron 6:889-900.

Edwards FA, Konnerth A, Sakmann B, Takahashi T (1989) A thin slice preparation for patch clamp recordings from neurones of the mammalian central nervous system. Pflügers Arch 414:600-612.

Fenwick EM, Marty A, Neher E (1982) A patch-clamp study of bovine chromaffin cells and of their sensitivity to acetylcholine. J Physiol (Lond) 331:577-597.

Ford APDW, Williams TJ, Blue DR, Clarke DE (1994) $\alpha_{1}$-Adrenoceptor classification: sharpening Occam's razor. Trends Pharmacol Sci 15:167-170.

Frotscher M, Leranth C (1988) Catecholaminergic innervation of pyramidal and GABAergic nonpyramidal neurons in the rat hippocampus. Histochemistry 88:313-319. 
Gerber U, Greene RW, McCarley RW, Haas HL (1990) Excitation of brain stem neurons by noradrenaline and histamine. J Basic Clin Physiol Pharmacol 1:71-76.

Honda K, Takenaka T, Miyata-Osawa A, Terai M, Shiono K (1985) Studies on YM-12617: a selective and potent antagonist of postsynaptic $\alpha_{1}$-adrenoceptors. Naunyn Schmiedebergs Arch Pharmacol 328:264-272.

Horikawa K, Armstrong WE (1988) A versatile means of intracellular labelling: injection of bincytin and its detection with avidin conjugates. J Neurosci Methods 25:1-11.

Hughes IE, Smith JA (1978) The stability of noradrenaline in physiological saline solutions. J Pharm Pharmacol 30:124-126.

Johnson SW, North RA (1992) Opioids excite dopamine neurons by hyperpolarization of local interneurons. J Neurosci 12:483-488.

Kawaguchi Y, Hama K (1988) Physiological heterogeneity of nonpyramidal cells in rat hippocampal CA1 region. Exp Brain Res 72:494-502.

Knowles WD, Schwartzkroin PA (1981) Local circuit synaptic interactions in hippocampal brain slices. J Neurosci 1:318-322.

Kokaia M, Bengzon J, Kalen P, Lindvall O (1989) Noradrenergic mechanisms in hippocampal kindling with rapidly recurring seizures. Brain Res 491:398-402.

Lacaille J-C, Mueller AL, Kunkel DD, Schwartzkroin PA (1987) Local circuit interactions between oriens/alveus interneurons and CAl pyramidal cells in hippocampal slices: electrophysiology and morphology. $\mathrm{J}$ Neurosci 7:1979-1993.

Lacaille J-C, Schwartzkroin PA (1988a) Stratum lacunosum-moleculare interneurons of hippocampal $\mathrm{CA} 1$ region. I. Intracellular response characteristics, synaptic responses, and morphology. J Neurosci $8: 1400-1410$

Lacaille J-C, Schwartzkroin PA (1988b) Stratum lacunosum-moleculare interneurons of hippocampal CA1 region. II. Intrasomatic and inlradendritic recordings of local circuit synaptic interactions. J Neurosci 8:1411-1424.

Lacaille J-C, Williams S (1990) Membrane properties of interneurons in stratum oriens-alveus of the CA1 region of rat hippocampus in vitro. Neuroscience 36:349-359.

Lorente de No R (1934) Studies on the structure of the cerebral cortex. II. Continuation of the study of the ammonic system. J Psychol Neurol 46:113-177.

Loy R, Koziell DA, Lindsey JD, Moore RY (1980) Noradrenergic innervation of the adult rat hippocampal formation. J Comp Neurol 189:699-710.

Madison DV, Nicoll RA (1986) Actions of noradrenaline recorded intracellularly in rat hippocampal CA1 pyramidal neurones in vitro. J Physiol (Lond) 372:221-244.

Madison DV, Nicoll RA (1988a) Norepinephrine decreases synaptic inhibition in the rat hippocampus. Brain Res 112:131-138.

Madison DV, Nicoll RA (1988b) Enkephalin hyperpolarizes interneurones in the rat hippocampus. J Physiol (Lond) 398:123-130.

Mayer ML, Westbrook GL (1983) A voltage-clamp analysis of inward (anomalous) rectification in mouse spinal sensory ganglion neurons. $\mathrm{J}$ Physiol (Lond) 340:19-45.

McBain CJ, DiChiara TJ, Kauer JA (1994) Activation of metabotropic glutamate receptors differentially affects two classes of hippocampal interneurons and potentiates excitatory synaptic transmission. J Neurosci $14: 4433-4445$.

McCormick DA, Pape H-C (1990a) Properties of a hyperpolarizationactivaled cation current and its role in thythmic oscillation in thalamic relay neurons. J Physiol (Lond) 431:291-318.

McCormick DA, Pape H-C (1990b) Noradrenergic and serotonergic modulation of a hyperpolarization-activated cation current in thalamic relay neurons. J Physiol (Lond) 431:319-342.

McCormick DA, Prince DA (1988) Noradrenergic modulation of firing pattern in guinea pig and cat thalamic neurons in vitro. J Neurophysiol 59:978-996.

McIntyrc DC, Guigno L (1988) Effect of clonidine on amygdala kindling in normal and 6-hydroxydopamine-pretreated rats. Exp Neurol 99:96-106.

McLean S, Kothman RB, Jacobson AE, Rice K, Herkenham M (1987) Distribution of opiate receptor subtypes and enkephalin and dynorphin immunoreactivity in the hippocampus of the squirrel, guinea pig, rat, and hamster. J Comp Neurol 255:497-510.

Miles R, Wong RKS (1984) Unitary inhibitory synaptic potentials in guinea-pig hippocampus in vitro. J Physiol (Lond) 356:97-113.
Milner TA, Bacon CE (1989a) Ultrastructural localization of tyrosine hydroxylase-like immunoreactivity in the rat hippocampal formation. $J$ Comp Neurol 281:479-495.

Milner TA, Bacon CE (1989b) GABAergic neurons in the rat hippocampal formation: ultrastructure and synaptic relationships with catecholaminergic terminals. J Neurosci 9:3410-3427.

Mueller AL, Dunwiddie TV (1983) Anticonvulsant and proconvulsant actions of alpha- and beta-noradrenergic agonists on epileptiform activity in the rat hippocampus in vitro. Epilepsia 24:57-64.

Mueller AL, Hoffer BJ, Dunwiddie TV (1981) Noradrenergic responses in rat hippocampus: evidence for mediation by alpha and beta receptors in the in vitro slice. Brain Res 214:113-126.

Mueller AL, Palmer MR, Hoffer BJ, Dunwiddie TV (1982) Hippocampal noradrenergic responses in vivo and in vitro: characterization of alpha and beta components. Naunyn Schmiedebergs Arch Pharmacol 318:259-266.

Neuman RS (1986) Suppression of penicillin-induced focal epileptiform activity by locus coeruleus stimulation: mediation by an $\alpha_{1^{-}}$ adrenoceptor. Epilepsia 27:359-366.

Nicoll RA, Alger BE, Jahr CE (1980) Enkephalin blocks inhibitory pathways in the vertebrate CNS. Nature 287:22-25.

Nicoll RA, Malenka RC, Kauer JA (1990) Functional comparison of neurotransmitter receptor subtypes in mammalian central nervous system. Physiol Rev 70:513-565.

Olbrich H-G, Braak H (1985) Ratio of pyramidal cells versus nonpyramidal cells in sector CA1 of the human Ammon's horn. Anat Embryol 173:105-110.

Oleskevich S, Descarries L, Lacaille J-C (1989) Quantified distribution of the noradrenaline innervation in the hippocampus of adult rat. $J$ Neurosci 9:3803-3815.

Otis 'IS, Mody I (1992) Modulation of decay kinetics and frequency of $\mathrm{GABA}_{\mathrm{A}}$ receptor-mediated spontaneous inhibitory postsynaptic currents in hippocampal neurons. Neuroscience 49:13-32.

Otis TS, Staley KJ, Mody I (1991) Perpetual inhibitory activity in brain slices generated by spontaneous GABA release. Brain Res 545:142-150.

Pan 7.7., Grudt TI, Williams IT (1994) $\alpha_{1}$-Adrenoceptors in rat dorsal raphe neurons: regulation of two potassium conductances. J Physiol (Lond) 478:437-447.

Pang K, Rose GM (1987) Differential effects of norepinephrine on hippocampal complex-spike and theta-neurons. Brain Res 425:146-158.

Pang K, Rose GM (1989) Differential effects of methionine ${ }^{5}$-enkephalin on hippocampal pyramidal cells and interneurons. Neuropharmacology 28:1175-1181.

Pape H-C, McCormick DA (1989) Noradrenaline and serotonin selectively modulate thalamic burst firing by enhancing a hyperpolarization activated cation conductance. Nature 340:715-718.

Pieribone VA, Nicholas AP, Dagerlind A, Hokfelt T (1994) Distribution of $\alpha_{1}$ adrenoceptors in rat brain revealed by in situ hybridization experiments utilizing subtype-specific probes. J Neurosci 14:4252-4268.

Press WH, Flannery BP, Teukolsky SA, Vetterling WT (1986) Are two distributions different? Kolmogorov-Smirnov test. In: Numerical recipes: the art of scientific computing, pp 472-475. New York: Cambridge UP.

Ramon y Cajal S (1911) Histologie du systeme nerveux de l'homme et des vertebres. Paris: Maloine,

Randle JCR, Bourque CW, Renaud LP (1986) $\alpha_{1}$-Adrenergic receptor activation depolarizes rat supraoptic neurosecretory neurons in vitro. Am J Physiol 251:R569-R574.

Scanziani M, Gahwiler BH, Thompson SM (1993) Presynaptic inhibition of excitatory synaptic transmission mediated by $\alpha$-adrenergic receptors in area CA3 the rat hippocampus in vitro. J Neurosci 13:5393-5401.

Schwartzkroin PA, Mathers CH (1978) Physiological and morphological indentification of a nonpyramidal cell type. Brain Res 157:1-10.

Schwartzkroin $P \Lambda$, Prince DA (1980) Changes in excitatory and inhibitory synaptic potentials leading to epileptogenic activity. Brain Res 183:61-76.

Segal M, Bloom FE (1974a) The action of norepinephrine in the rat hippocampus. I. Iontophoretic studies. Brain Res 72:79-97.

Segal M, Bloom FE (1974b) The action of norepinephrine in the rat hippocampus. II. Activation of the input pathway. Brain Res 72:99-114. Solomon JS, Nerbonne JM (1993) Hyperpolarization-activated currents in isolated superior colliculus-projecting neurons from rat visual cortex. J Physiol (Lond) 462:393-420.

Soltesz I, Mody I (1994) Patch-clamp recordings reveal powerful GABAergic inhibition in dentate hilar neurons. J Neurosci 14:2365-2376. 
Spruston N, Johnston D (1992) Perforated patch-clamp analysis of the passive membrane properties of three classes of hippocampal neurons. J Neurophysiol 67:508-529.

Stevens DR, McCarley RW, and Greene RW (1994) The mechanism of noradrenergic $\alpha_{1}$ excitatory modulation of pontine reticular formation neurons. J Neurosci 14:6481-6487.

Unnerstall JR, Kuhar MJ (1988) Mapping the $\alpha$-adrenergic receptor in the central nervous system: a guide to structure and function. In: Epinephrine in the central nervous system (Stolk JM, U'Prichard DC, Fuxe K, eds), pp 45-59. New York: Oxford UP.

Vaney DI (1991) Many diverse types of retinal neurons show tracer coupling when injected with biocytin or neurobiotin. Neurosci Lett 125:187-190.

Virtanen R, Savola J-M, Saano V (1989) Highly selective and specific antagonism of central and peripheral $\alpha_{2}$-adrenoceptors by atipamezole. Arch Int Pharmacol Ther 297:190-204.
Weiss GK, Lewis J, Jimenez-Rivera C, Vigil A, Corcoran ME (1990) Antikindling effects of locus coeruleus stimulation: mediation by ascending noradrenergic projections. Exp Neurol 108:136-140.

Williams JT, Henderson G, North RA (1985) Characterization of $\alpha_{2}$ adrenoceptors which increase potassium conductance in rat locus coeruleus neurones. Neuroscience 14:95-101.

Woodson W, Nitecka L, Ben-Ari Y (1989) Organization of the GABAergic system in the rat hippocampal formation: a quantitative immunocytochemical study. J Comp Neurol 280:254-271.

Zieglgansberger W, French ED, Bloom FE (1979) Opioid peptides may excite hippocampal pyramidal neurons by inhibiting adjacent inhibitory interneurons. Science 205:415-417.

Zilles K, Gross G, Schleicher A, Schildgen S, Bauer A, Bahro M, Schwendemann $G$, 7ech $K$, Kolassa $N$ (1991) Regional and laminar distributions of $\alpha_{1}$-adrenoceptors and their subtypes in human and rat hippocampus. Neuroscience 40:307-320. 